\title{
THE MALLEABILITY OF PATENT RIGHTS
}

\author{
Jason Rantanen* \\ 2015 Mich. ST. L. REV. 895
}

\begin{abstract}
The core insight of this Article is that patent rights are not static and fixed, as they are commonly portrayed, but malleable. Commentators typically treat patent rights as if they are unchanging, frozen forever at the moment the patent issues. But patent law isn't so limited. Patent rights are surprisingly malleable: The scope and strength of the right can be changed even after the patent is issued through a surprisingly large array of mechanisms, allowing actors operating within the patent system the ability to change the very contours of individual patents. Malleability thus adds an important layer onto previous work recognizing that patent rights are uncertain: It is not merely that patent rights can involve something akin to a roll of the dice or an inability to definitively pin down their scope, but that the outcome of that roll or the contours of the uncertainty can be changed by the actions of the parties involved.

This Article develops the concept of malleable rights, a new lens through which to view patents, and distinguishes the idea of malleable rights from that of probabilistic rights. Using this concept, the Article explores the ways in which patent rights are malleable and examines possible theoretical justifications for the malleability of patent rights, concluding that regardless of whether one accepts such justifications, recognizing the malleability of patent rights has profound consequences for discussions about emerging patent monetization strategies, for the patent system as a whole, and perhaps for views about rights over intangibles generally.
\end{abstract}

* Associate Professor, University of Iowa College of Law. I thank Christina Bohannan, Steve Burton, Tun-Jen Chiang, Tom Cotter, John Duffy, Richard Epstein, Paul Gowder, Tim Holbrook, Herbert Hovenkamp, Mark Lemley, Lisa Larrimore Ouellette, Oskar Liivak, Peter Menell, Robert Miller, Todd Pettys, Michael Risch, Dave Schwartz, Jacob Sherkow, Greg Vetter, and the audience members and participants at the Drake Intellectual Property Roundtable, the Patent Conference 4, Vanderbilt IP Scholars Roundtable, and the Iowa Legal Studies Workshop for very helpful discussions about the project and comments on earlier drafts. 


\section{TABLE OF CONTENTS}

INTRODUCTION 896

I. CONVENTiOnal Views OF THE NATURE OF THE PATENT

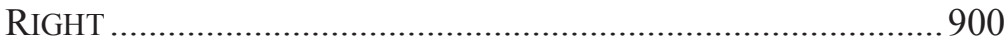

II. CERTAINTY AND PROBABILITY ................................................ 907

A. Certain Rights Versus Probabilistic Rights .....................907

B. Patent Rights as Probabilistic Rights ............................... 909

III. FIXED VERSUS MALLEABLE ..............................................916

A. The Concept of Malleability ...........................................9916

B. Patent Rights as Malleable Rights ...................................919

C. The Elastic Leash on Patent Claims ................................9919

D. The Game of Claim Construction.................................... 928

E. Patents as Multiple, Semi-Independent Bundles of

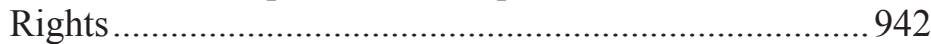

F. Post-Issuance Revision at the Patent Office ...................9945

G. Malleability and Patent Portfolios ....................................946

IV. IS THERE A THEORETICAL JUSTIFICATION FOR THE MALLEABILITY OF PATENT RIGHTS? .....................................948

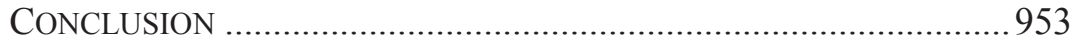

\section{INTRODUCTION}

Some persons seem to suppose that a claim in a patent is like a nose of wax, which may be turned and twisted in any direction, by merely referring to the specification, so as to make it include something more than, or something different from, what its words express. ... The claim is a statutory requirement, prescribed for the very purpose of making the patentee define precisely what his invention is; and it is unjust to the public, as well as an evasion of the law, to construe it in a manner different from the plain import of its terms. This has been so often expressed in the opinions of this court that it is unnecessary to pursue the subject further.

Justice Bradley, White v. Dunbar $(1886)^{1}$

Every patent lawyer knows at least the first few lines of this sacred mantra from White v. Dunbar. The case involved a patented process for canning shrimp. Conventional canning methods had typically involved placing food in a can, sealing the can, then boiling or steaming it all. ${ }^{2}$ When shellfish contact a metal can, however, they

1. White v. Dunbar, 119 U.S. 47, 51-52 (1886).

2. For a history of the technological developments surrounding canning and its importance in the late nineteenth and twentieth centuries, see SUE SHEPHARD, Pickled, Potted, and Canned: How the Art and Science of Food Preserving 
produce a "profus[ion] . . . of a black substance, generally believed to be sulphur." Since diners generally prefer not to consume smelly black shrimp, the Dunbars ${ }^{4}$ developed a solution: place the shrimp in a fabric bag to prevent direct contact with the metal can. They patented this process, claiming a canning process in which a "textile fabric" was interposed between the walls of the can and the shrimp. ${ }^{5}$ Apparently unsatisfied with the original scope of the claim, the Dunbars later sought and obtained a reissuance ${ }^{6}$ that simply required "an enveloping material for the shrimps." Perhaps this was because a competitor had begun using sheets of wax-coated paper in its cans of shrimp. ${ }^{8}$

But in the $1880 \mathrm{~s}$, as now, new claims resulting from a reissuance were not permitted to exceed the scope of the patent's original claims." And the Supreme Court concluded the "textile fabric" claims did exactly that. ${ }^{10}$ In this context, Justice Bradley uttered those famous words, the premise being that patent rights are not malleable "like a nose of wax."

Changed the World 226-256 (2000). The United States was at the forefront of this movement: "By the 1870s America was packing more different kinds of food in far larger quantities than any other country." Id. at 247.

3. White, 119 U.S. at 51.

4. The inventors listed on the patent are George W. Dunbar, George H. Dunbar, and Francis B. Dunbar. See U.S. Patent No. 178,916 (filed Feb. 1, 1876). According to one account, however, it was George W.'s wife who actually suggested the use of a muslin bag in the cans. See 65 Years of Mississippi Seafood History, Daily Herald, July 3, 1933, at 16. For a short history of the G.W. Dunbar Sons Canning Factory, see Edmond Boudreaux, The Seafood Capital of the WORLD: BILOXI's MARITIME HISTORY 48-49 (2011).

5. '916 Patent.

6. A reissuance is a process whereby a patent is surrendered to the patent office and new claims requested. 35 U.S.C. § 251(a) (2012).

7. White, 119 U.S. at 48-49; U.S. Patent No. 9,957 (filed Apr. 9, 1881) (reissued Dec. 6, 1881).

8. White, 119 U.S. at 49.

9. There are exceptions; for example, under current law a broadening claim may be sought within two years of issuance of the surrendered patent. 35 U.S.C. $\S 251(d)$.

10. White, 119 U.S. at 49-50 ("The claim in the original patent was for placing textile fabric between the can and its contents; whilst in the reissue it is for interposing between the metal can and the shrimps an enveloping material for the shrimps. This is certainly, on its face, a very important enlargement of the claim; and we see nothing in the context of the specification in the original patent which could possibly give the claim so broad a construction.").

11. Id. at 51. I use the term "patent rights" to refer to the fundamental idea that patents imbue their owners with certain exclusive rights such as the exclusive right to make, use, offer for sale, and sell the invention, wherein "the invention" is 
Yet, Justice Bradley was wrong, at least as a descriptive matter. Patent rights are malleable. Fixation - a nose of stone rather than a nose of wax - may be a normative goal, but it is not reality. And, as the very concept of the reissued claim at issue in White v. Dunbar indicates, patent rights are malleable at least in part by deliberate design. This is not to say that patent rights are just unformed clay, waiting to be manipulated into a shape pleasing to the crafter: The constraints imposed in White illustrate that there are limits. But within those limits, which can sometimes be quite broad and themselves flexible, patent rights are imbued with substantially more malleability than conventional views assume.

This Article develops the concept of malleability in the context of patent law. In defining malleability, I distinguish it from the idea that patent boundaries are merely probabilistic, a characteristic already recognized by the literature. ${ }^{12}$ "Probabilistic" refers to the idea that patent rights are not certain as long as they are alive. ${ }^{13}$ There is nearly always some degree of uncertainty over the scope of a

understood to mean the invention as claimed in the patent. See, e.g., 35 U.S.C. $\S 154$ (a) (2015). As I discuss in Section III.C, patents are really made up of a set of claims, each which makes use of different language to claim the same invention. At least that's the idea in theory. In practice, patent claims function in a much more complex way. However, for purposes of laying out the basic concept here, referring to the knot of rights over an invention granted by a patent as "patent rights" should be sufficient.

12. See, e.g., Mark A. Lemley \& Carl Shapiro, Probabilistic Patents, 19 J. ECON. PERSP. 75, 75 (2005) (observing that "[f]or many years, economists typically conceptualized patents as well-defined property rights" but noting that this belief has changed more recently). Lemley and Shapiro identify two types of uncertainty in patents: "1) uncertainty about the commercial significance of the invention being patented, and 2) uncertainty about the validity and scope of the legal right being granted." Id. at 76. It is the second type of uncertainty that I refer to here. There is another type of uncertainty frequently ascribed to patents, that of indeterminacy. See, e.g., Adam Mossoff, The Trespass Fallacy in Patent Law, 65 FlA. L. REV. 1687, 1689-92 (2013) (describing the indeterminacy critique in patent law). While a thin line could be drawn that parses probability from indeterminacy (the former is one of chance while the latter relates more to the ability of words to describe things), the underlying point is that the results are uncertain. Both probability and indeterminacy involve the same basic concept: that we do not know exactly what the outcome will be. For this reason, I don't dig deeply into the difference here. That said, to the extent one characterizes claims as primarily involving an indeterminacy problem, it inevitably manifests as the probabilistic nature of patent litigation.

13. Of course, once a patent claim has been adjudicated to be invalid, and all avenues of appeal exhausted, then the validity and scope of that patent right is no longer uncertain: The patent right is dead as a doorknob. But at that point the right has ceased to be a right; it is now nothing. 
given patent and its validity. ${ }^{14}$ A person who studies a patent can certainly make probabilistic determinations about issues of validity and scope, just as a casino patron can conclude that a roulette ball is more likely to land on red than "zero." But even the best, most careful, most sophisticated patent attorney is unlikely to offer a conclusion about a patent's validity and scope with absolute confidence. Recognizing patent rights as probabilistic has had important implications for our collective understanding of patents.

Equally important, however, is the idea that patent rights are malleable: that the very rights themselves can be altered by the actors who interact with the issued patent. In other words, the answers to questions about patent validity and scope can be changed by the actions of the patent's owners and potential infringers. Patent rights can be pushed and pulled. Their very existence and shape can be changed through an array of legal mechanisms. Of course, because patent rights are both probabilistic and malleable, actors interacting with patents are rarely able to influence those rights with absolute certainty. At best, they can affect the probabilities involved, much like a skilled poker player. Yet despite a patent's uncertainties, the point remains that those probabilities can be affected by the actors who interact with the patent. This concept - that patent rights are malleable - has never before been developed in the literature outside of a few articles discussing a specific, narrow form of malleability. ${ }^{15}$

14. While patents are imbued with a presumption of validity upon issuance, that presumption is merely that: a presumption.

15. The closest work to the concept of malleability that I advance here is in two strands: claim interpretation and post-issuance amendment at the patent office. The claim interpretation literature seeks to grapple with the uncertainties that are inherent in interpreting patent language, either because of linguistic ambiguity, see Dan L. Burk \& Mark A. Lemley, Fence Posts or Sign Posts? Rethinking Patent Claim Construction, 157 U. PA. L. REV. 1743, 1752-53 (2009), or because of policy conflicts, see, e.g., Tun-Jen Chiang \& Lawrence B. Solum, The InterpretationConstruction Distinction in Patent Law, 123 YALE L. J. 530, 533-34 (2013). It tends to focus on whether or not claim boundaries are uncertain, why that might be so, and what the consequences of that uncertainty might be, and thus is really about probabilistic rights rather than malleability. A second, arguably closer, strand of scholarship is that dealing with the ability of parties to amend the formal shape of their claims after issuance through post-issuance proceedings at the patent office. Tun-Jen Chiang's work, in particular, points out that these mechanisms allow claims to "be explicitly changed throughout the patent's lifetime, thereby moving the patent boundary" and he argues that "issued patents should not be amended." Tun-Jen Chiang, Fixing Patent Boundaries, 108 Mich. L. ReV. 523, 525 \& 526 (2010). The ability to formally change patent claims through patent office proceedings is an 
The concept of malleable rights could arguably apply to other rights beyond patent law. Indeed, taken to its extreme, fundamental rights such as the right of possession over a lawfully purchased chattel could be argued to be malleable. However, I do not make such a broad claim here. My point is not that all legal rights are just a lump of clay that skilled hands can form into any shape ex post. Rather, I define and describe the concept of malleability and demonstrate that patent rights are surprisingly malleable. To be clear: my account is largely descriptive, although I do consider some possible normative justifications for and concerns about malleability towards the end.

The remainder of this Article proceeds as follows. Part I provides an introduction to the way that patent rights are typically conceptualized as fixed rights. Part II describes the view that patent rights are probabilistic, which is a necessary precursor to the concept of malleability. Part III sets out the concept of malleability and explains how patent rights are malleable. Finally, Part IV explores possible theoretical justifications for malleability in patent rights.

\section{CONVENTIONAL Views of the NAture of the PATENT Right}

Implicit — and sometimes explicit—in discussions about patent rights is an assumption that those rights are fixed at the moment the patent issues. Below, I offer a few examples to illustrate how the law and literature assume the fixed nature of patent rights.

An obvious starting point is the granting statute, which has remained largely unchanged since $1952 .{ }^{16}$ In reading the language of

important part of what makes patent rights malleable, but it is only one piece of what makes patent rights malleable.

16. Patent Act of 1952, Pub. L. No. 82-593 ch. 950, 66 Stat. 792 (1952), provides the core statutory elements governing patent law today. See JANICE M. Mueller, Patent Law 33 ( 3 d ed. 2009). While earlier incarnations of the patent law contain similar concepts and wording, virtually all post-1952 commentary focuses on the 1952 Act and any relevant subsequent amendments. To be sure, Article I, $\S 8$, Clause 8 of the U.S. Constitution, which authorizes Congress " $\mathrm{t}] \mathrm{o}$ promote the Progress of Science and useful Arts, by securing for limited Times to Authors and Inventors the exclusive Right to their respective Writings and Discoveries" is technically the starting point. U.S. CONST. art. I, $\S 8, \mathrm{cl}$. 8. This provision, however, simply establishes the outer boundaries of what Congress can do and perhaps what the scope of the exclusive right might be. See Graham v. John Deere Co. of Kan. City, 383 U.S. 1, 5-6 (1966) ("The Congress in the exercise of the patent power may not overreach the restraints imposed by the stated constitutional purpose."). It is the implementing statute that actually provides virtually all of the meaningful contours of that right. 
the current text in $\S 154$, note how it describes those rights, particularly with its use of the term "the invention":

\section{U.S.C. $§ 154$ - Contents and term of patent; provisional rights}

(a) In General.-

(1) Contents. - Every patent shall contain a short title of the invention and a grant to the patentee, his heirs or assigns, of the right to exclude others from making, using, offering for sale, or selling the invention throughout the United States or importing the invention into the United States ... referring to the specification for the particulars thereof. ${ }^{17}$

With this passage, the patent law offers the prospect of exclusive rights over "the invention." And of course we all know what "the invention" is: If it were an unclear concept, certainly the statute would define it! ${ }^{18}$ Nowhere does the statute suggest that those rights can change; to the contrary, the reference to "the invention" implies that there is a thing - the invention - to which rights are being granted. ${ }^{19}$ Language elsewhere in the patent statute is similar: Section 112, for example, requires "a written description of the invention." 20 The statute thus ties the patent rights to the invention, as if it were a concept that everyone understood as plain as day. ${ }^{21}$

17. 35 U.S.C. $§ 154$ (2012).

18. And it does. But not really. See 35 U.S.C. § 100(a) ("The term 'invention' means invention or discovery.").

19. For purposes of describing the core concept of malleability, I don't see it mattering a great deal whether one takes a view of the invention-as-specification or invention-as-claim view; both are malleable. See infra note 93.

20. 35 U.S.C. $\S 112$ (a) (emphasis added); see also 35 U.S.C. § 271(a) (2012) (referencing "any patented invention" in stating the action for patent infringement).

21. Although it is not directly relevant to the main point of this Article, "the invention" is hardly such an easy concept. As Oskar Liivak has demonstrated, the conventional assertion that "the claim" is synonymous with "the invention" is inherently faulty. See Oskar Liivak, Rescuing the Invention from the Cult of the Claim, 42 Seton Hall L. Rev. 1, 3-6 (2012). Nor has the literature assembled a coherent understanding of the statutory meaning of "the invention." See id. at 4 ("[A] substantive discussion of the invention as a statutory concept is nowhere to be found in modern patent doctrine or scholarship."). Liivak himself offers such a meaning from a disclosure-centric perspective, but that meaning is not one that all agree on. See Tun-Jen Chiang, Forcing Patent Claims, 113 Mich. L. REv. 513, 52526 (referring to Liivak's approach as a hollow standard). More importantly, Liivak's proposed meaning draws implicitly on a fixed conception of the patent rights: The invention as disclosed serves as an anchor for the claims. See Liivak, supra, at 6 ("The claims are not abstract legal boundaries, but rather, they "particularly point[] out and distinctly claim[]' the actual substantive invention described by the specification."). 
This makes sense, particularly when one recognizes that modern U.S. patent law is deeply rooted in a nineteenth century manufacturing and agrarian world. In such a world, where inventions take the form of plows, cotton bale ties, and rubber vulcanization methods, "the invention" can assume a relatively clear form. ${ }^{22}$ Indeed, between 1836 and 1870, inventors were required to submit models of their inventions to the patent office. ${ }^{23}$ The invention as a thing, a rem, was a perfectly logical assumption in such a world. ${ }^{24}$

While modern views of "the invention" have moved away from seeing an invention as a "thing" and towards viewing it as a more abstract bundle of rights, ${ }^{25}$ they nevertheless retain the conception of those rights as fixed and unchanging. Consider Rebecca Eisenberg's work on the experimental use exception (with emphases added):

A United States patent confers the exclusive right to make, use, and sell the invention set forth in the patent claims in the United States for seventeen years. During the term of the patent the patent holder has the right to stop anyone from using the invention-even an innocent infringer who develops the same invention independently. ${ }^{26}$

22. See Jeanne C. Fromer, Patent Disclosure, 94 Iowa L. Rev. 539, 574 n.152 (2009) (" $[\mathrm{I}]$ nventions early in the history of the American patent system tended to be available commercially and also to be simple and mechanical in nature....").

23. See Sean B. Seymore, The Teaching Function of Patents, 85 Notre DAME L. ReV. 621, 642 n.103 (2010) (describing the model requirement).

24. Cf. Edmund W. Kitch, The Nature and Function of the Patent System, 20 J. L. \& ECON. 265, 268 (1977) ("We tend to think of the invention as the thing an inventor has made or accomplished, and the rule seems to imply the inventor is confined to that."). This is not to say that patent boundaries or questions of validity or disclosure were necessarily simple, or that the concept of malleability that I describe here cannot be seen in nineteenth-century patent law. Rather, I'm merely pointing out that viewing the invention as a fixed "thing" makes a great deal of sense if one considers the historical context from which the modern concept of "the invention" emerged.

25. See Liivak, supra note 21 , at 47 ("We have been taught that invention is not the right way for the initiated to discuss patent law. The concrete usage of the invention, referring to the thing actually invented, has fallen victim to modern patent law's cult of the claim."); Kitch, supra note 24, at 268 ("We tend to think of an invention as the thing an inventor has made or accomplished, and the rule seems to imply the inventor is confined to that. But the rule is misleading, because the invention as claimed in the patent claims and the physical embodiment of the invention are two quite different things.").

26. See Rebecca S. Eisenberg, Patents and the Progress of Science: Exclusive Rights and Experimental Use, 56 U. CHI. L. REV. 1017, 1021 (1989) [hereinafter Progress of Science] (emphases added) (footnote omitted). 
In this explanation - and indeed, throughout the paperEisenberg refers to "the invention" or "the patented invention." ${ }^{27}$ Read in the context of the paragraph above and the work as a whole, "the invention" operates as a stationary construct; it is the very thing that the patent holder is allowed to stop others from using. This reading, of course, flows naturally from the language of the statute itself. During the term of the patent, ${ }^{28}$ others cannot use "the same invention" without the patent holder's permission. The problem that Eisenberg identifies is that this exclusive right is broad enough to penetrate even the sphere of basic research. ${ }^{29}$ The solution, then, is to develop a coherent and well-supported experimental use exception, one that has a "proper scope." 30

Eisenberg's treatment of "the invention" is representative. Countless commentators use the exact same phrase in the same way: ${ }^{31}$ as a shorthand to invoke a general understanding of a set of

27. See, e.g., id. at 1022 ("In exchange for these exclusive rights, the patent statute requires the inventor to disclose the invention in the patent application ...." (emphasis added)); id. at 1070 ("Exclusive patent rights are seen as an alternative to secrecy because patent protection makes secrecy impossible (by requiring disclosure of the invention in order to get a patent) and unnecessary (by conferring exclusive rights that survive disclosure)." (emphasis added)); id. at 1078 ("Research use of $a$ patented invention with a primary or significant market among research users should not be exempt from infringement liability when the research user is an ordinary consumer of the patented invention." (emphases added)). Each of these uses of "the invention" (or the "patented invention") treats it as both a static concept to which the patent right exists in parallel.

28. At the time Eisenberg wrote the Progress of Science article, the patent term was seventeen years from issuance at the time. See Craig Allen NARD, The LAW OF PATENTS $1 \mathrm{n} .3$ (3d ed. 2014). In 1995, the patent term of a patent was changed to twenty years from the filing date for applications filed on or after June 8 , 1995. Id.

29. Progress of Science, supra note 26, at 1017-18.

30. Id. at 1022 .

31. Continuing in the experimental-use-exception literature, writing a decade later, Katherine Strandburg formulated the idea of self-disclosing and nonself-disclosing inventions. See Katherine J. Strandburg, What Does the Public Get? Experimental Use and the Patent Bargain, 2004 WIS. L. REV. 81, 83 (2004). This work also speaks of the patent right in terms similar to that of Professor Eisenberg. "Patents" and "inventions" are, if not used almost interchangeably, then certainly equated with one another. See id. at 91 ("The effect patents have on technological progress is complicated because, in principle, most inventions have the potential to benefit society in two ways: (1) through their direct utility to the users or consumers of embodiments of the invention; and (2) through the use of the inventive idea as a springboard to further innovation."). Interestingly, the pivotal case in What Does the Public Get? Experimental Use and the Patent Bargain, Madey v. Duke University, 307 F.3d 1351, 1352 (Fed. Cir. 2002), involved a situation where there was no 
fixed, if perhaps fuzzy and abstract, rights. Courts, too-particularly, the Supreme Court-draw upon this terminology, particularly when emphasizing the immutable nature of whatever is being patented. ${ }^{32}$ This stands to reason: After all, the patent statutes themselves invoke the term throughout.

dispute that the accused infringer was using the literal embodiment of the claimed invention - it was, after all, Dr. Madey's own free electron laser that Duke was continuing to use. Here, then, it seems to make perfect sense to take a view of the patent right and the invention as being one and the same.

More recently yet, Jonas Anderson's work, which builds on Strandburg's idea of self- and non-self-disclosing inventions, constructs an analytical structure in which to neatly compartmentalize the question of whether innovations should be protected through patents or trade-secrecy laws. See J. Jonas Anderson, Secret Inventions, 26 BERKELEY TECH. L. J. 917, 921-21 (2011). While Anderson emphasizes the limits of patent law's current disclosure rules and the ability of patent holders to claim more than they disclose, he simultaneously speaks of the rights using the language of "the invention" or "the innovation." See id. at 941-45. The inference is that the patent rights are fixed and unchanging, or at least not subject to change after issuance.

I have, obviously, oversimplified each of these scholars' contributions to illustrate the idea of a relatively stationary patent right. They all possess a deep understanding of patent law and thus recognize how questions of validity and claim scope can, in practice, shift and move. But underlying much of the work in the field is a subconscious treatment of the patent right as fixed, one that manifests itself particularly through the language of "the invention."

32. Consider, for example, the Court's discussion of patent rights in its recent subject matter jurisprudence. There, the Court implicitly conceptualized "the invention" as a static construct for purposes of the subject matter eligibility inquiry. This is most striking in Alice Corp. Pty. Ltd. v. CLS Bank International, $134 \mathrm{~S}$. Ct. 2347 (2014), where the Court emphasized what it perceived as the "substance" of the claimed rights:

Put another way, the system claims are no different from the method claims in substance. The method claims recite the abstract idea implemented on a generic computer; the system claims recite a handful of generic computer components configured to implement the same idea. This Court has long "warn[ed] . . . against" interpreting $\S 101$ "in ways that make patent eligibility 'depend simply on the draftsman's art.",

Id. at 2360 (quoting Mayo Collaborative Servs. v. Prometheus Labs., Inc., 132 S. Ct. $1289,1294(2012))$. The idea here is that there is some true "invention," of which everything else is merely a shadow. This, too, is a manifestation of a view of patent rights as fixed, although it is very different from that taken by, say, the Federal Circuit. See, e.g., Ultramercial, Inc. v. Hulu, LLC, 722 F.3d 1335, 1348 (Fed. Cir. 2013) (concluding that meaningful limitations involving computers may make a claimed invention patent eligible) cert. granted, vacated, WildTangent, Inc. v. Ultramercial, LLC, 134 S. Ct. 2870 (2014); see also Christopher A. Cotropia, What is the "Invention"?, 53 WM. \& MARY L. REV. 1855, 1861-62 (2012) (distinguishing between the "external invention" and the "claim-centered invention"). 
As a second example of the language used to characterize patent rights, consider the classic rhetorical device in patent litigation discussed in the introduction: the "nose of wax" potency of this device is predicated on the idea that the patent right is - or at least, should be-immutable upon issuance. In its first appearance, Justice Bradley invoked this device to make clear that a claim in a patent may not "be turned and twisted in any direction, by merely referring to the specification, so as to make it include something more than, or something different from, what its words express. ${ }^{34}$ In the years since, courts have drawn upon Bradley's language to reject parties' attempts to interpret claims one way for validity and another way for infringement; ${ }^{35}$ to reject attempts to use one claim meaning during the patent examination process and another in litigation; ${ }^{36}$ and to reiterate the basic idea that claims are not so mutable. ${ }^{37}$ Parties draw upon the device whenever they wish to push the theme that their opponents are departing from the "true" meaning of the claims. ${ }^{38}$ Treatise writers use the device to explain that there is "no "nose of wax": "the specification cannot be used to alter an otherwise clear meaning of a claim term." 39 The central idea underlying all of these examples is that the patent claim cannot possibly be understood as mutable; it is fixed at the time of issuance, and to depart from that principle is a legal error.

Theories of patent law, too, inherently draw upon conceptions of patent rights as fixed. Indeed, the very calculations underlying the

33. A search of WestlawNext for the terms ("nose of wax"/p patent) in the Supreme Court and Federal Circuit databases returns 265 briefs. My own anecdotal experience is that this terminology is invoked even more frequently in the district courts.

34. White v. Dunbar, 119 U.S. 47, 51 (1886).

35. See Amazon.com, Inc. v. Barnesandnoble.com, Inc., 239 F.3d 1343, 1351 (Fed. Cir. 2001) ("A patent may not, like a 'nose of wax,' be twisted one way to avoid anticipation and another to find infringement." (quoting Sterner Lighting, Inc. v. Allied Elec. Supply, Inc., 431 F.2d 539, 544 (5th Cir. 1970)).

36. See Senmed, Inc. v. Richard-Allan Med. Indus., Inc., 888 F.2d 815, 819 n.8 (Fed. Cir. 1989) ("[A]n inventor may not be heard to proffer an interpretation that would alter the undisputed public record (claim, specification, prosecution history) and treat the claim as a "nose of wax." (citing Dunbar, 119 U.S. at 51)).

37. See Pratt \& Whitney Co. v. United States, 345 F.2d 838, 846-47 (Ct. Cl. 1965) ("Courts have long held that a claim is not "like a nose of wax, which may be turned and twisted in any direction' to make it include something not expressly recited." (citing Dunbar, 119 U.S. at 51)).

38. See 2A Barry Kramer \& Allen D. Brufsky, Patent law Practice FORMS $\S 77: 7.10$, Form 7(b)-6.1.

39. Robert A. Matthews, JR., 1 Annotated Patent Digest $\S 5: 6$ (2010). 
economics-based attempts to tweak and improve the patent system envision a patent that does not change once the proper rules are in place. Consider the economic explanation of patent rights offered by Richard Posner and William Landes. While their work recognizes the dynamic economic consequences of patents, it rests upon a conception of the rights themselves as something that is fixed at inception. In The Economic Structure of Intellectual Property Law, Landes and Posner discuss how a "patent protects against any duplication of the patented invention." 40 They assert that a patent allows its holder to obtain the "full value of the invention" "patents protect ideas." ${ }^{42}$ These characterizations draw upon the idea that the invention and the scope of rights are one, and that those rights are fixed at inception. More important than word choices, however, is their formal economic model of patents, which treats a patent as if it consists of exclusive rights over a particular new technology. The implication of the patent, Landes and Posner argue, is that the patented innovation impacts the cost structure, and thus the behavior of other firms competing in the market. ${ }^{43}$ This dynamic response, however, occurs even as the patent rights remain fixed; indeed, it would add another layer of complexity to Landes and Posner's formal model if the nature of the patent rights themselves changed even as competitors engaged in their own strategic behaviors.

The foregoing examples are not without a reasonable basis. Indeed, viewing patent rights as relatively certain and unchanging appears logical given the existence of a formally issued patent document coupled with its examination by a specialist at the federal government. After all, a patent seems to be a lot like a deed, except its subject is not land but technology. ${ }^{44}$ One just needs to read the document to know what technology it circumscribes.

40. William M. Landes \& Richard A. Posner, The Economic Structure of Intellectual Property LaW 295 (2004).

41. Id. at 301 .

42. Id. at 296 .

43. Id. at 297-98 (describing a formal economic model of the effects of a process patent on market-cost structure).

44. See, e.g., Phillips v. AWH Corp., 415 F.3d 1303, 1315 (Fed. Cir. 2005) (en banc) (quoting Hogg v. Emerson, 47 U.S. 437, 481-82 (1848)) ("[T]he specification is a 'component part of the patent' and 'is as much to be considered with the [letters patent] in construing them, as any paper referred to in a deed or other contract."'); In re Vamco Mach. \& Tool, Inc., 752 F.2d 1564, 1577 n.5 (Fed. Cir. 1985) ("The function of claims is (a) to point out what the invention is in such a way as to distinguish it from what was previously known, i.e., from the prior art; and 
Yet, as I explain in the remainder of this Article, such a view of patent rights fundamentally misunderstands both the legal structures around which they are built and how those rights actually work.

\section{CERTAINTY AND PROBABILITY}

The next two Parts lay out the central concept of this Article: the idea of malleability. The explanation draws on two axes: certain versus probabilistic and fixed versus malleable. The following image graphically presents the basic concept:

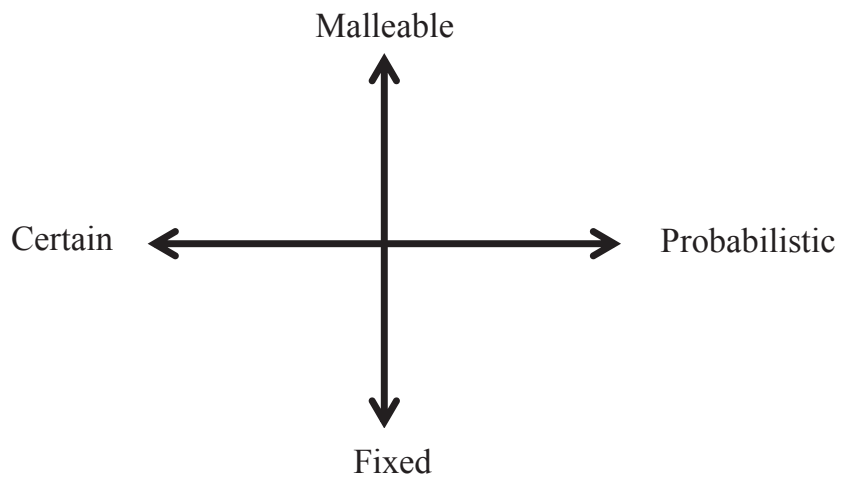

While modern scholars recognize patent rights as probabilistic, they have yet to explore the malleability axis. But to understand malleability, and how it differs from the concept of probabilistic rights, it is first necessary to explain the concepts of certainty and probability.

\section{A. Certain Rights Versus Probabilistic Rights}

Certainty is, at least on the surface, a straightforward concept: A result is certain when we are sure that it will occur. We are certain

(b) to define the scope of protection afforded by the patent. In both of those aspects, claims are not technical descriptions of the disclosed inventions but are legal documents like the descriptions of lands by metes and bounds in a deed which define the area conveyed but do not describe the land." (emphases omitted)); Christopher A. Cotropia, Patent Claim Interpretation Methodologies and Their Claim Scope Paradigms, 47 WM. \& MARY L. ReV. 49, 65 (2005) ("A claim resembles a land description in a deed because it defines the exact area protected by the legal instrument."). But see Emily Michiko Morris, Res or Rules? Patents and the (Uncertain) Rules of the Game, 18 Mich. Telecomm. \& Tech. L. Rev. 481, 494 (2012) (critiquing the conventional view of patent claims as property deeds). 
that the sun will rise in the east and set in the west, that day will follow night, and that water is wet. If one puts five blue marbles in an empty vase, and then draws out one marble, we can be certain that the marble will be blue. There are, unsurprisingly, epistemological disputes about what "certainty" is or should mean: Does it mean practical certainty? Or does it mean "absolute" certainty? ${ }^{45}$ In some legal contexts, this distinction might matter, such as when it comes to the level of proof for scientific facts. ${ }^{46}$ But for purposes of drawing the distinction between probabilistic and certain, the blue marble example should suffice.

The diametric opposite of certainty would logically seem to be absolute uncertainty. Yet, humans have developed an array of strategies for dealing with uncertainty. It is rare when we cannot predict at all what might happen. Even when results are unknown, there is still a degree of knowledge as to what might happen. As a result, rather than expressing the opposite of certainty as uncertainty, it is better understood as being probabilistic.

The basic idea of probability is that certain types of results are predictable - sort of. Put in more formal terms, probability refers to the idea that some results are more likely than others. ${ }^{47}$ What this means is that even though we cannot know the outcome of a particular event in advance, we can make predictions about what is likely to occur. Draw a card from a shuffled standard deck of playing cards and there's a $25 \%$ chance it will be a diamond and a $50 \%$ chance it will be a red suit. Roll two standard dice and there is a 4/36th chance that the result will add up to four. ${ }^{48}$

Consider a variation of the blue-marble scenario described above: An opaque vase contains five blue marbles and ninety-five

45. Compare John Stuart Mill, On Liberty and Other Essays 15 (2010) ("There is no such thing as absolute certainty, but there is assurance sufficient for the purposes of human life."), with RENE DESCARTES, Discourse ON Method and Meditations on First Philosophy 19 (Donald A. Cress trans., 3d ed. 1993) (developing a philosophical framework that is based on only that which is absolutely certain: "cogito ergo sum").

46. Jacob S. Sherkow, The Natural Complexity of Patent Eligibility, 99 IowA L. REV. 1137, 1155-66 (2014) (discussing concepts of certainty in the context of patent-eligible subject matter); Steve C. Gold, When Certainty Dissolves into Probability: A Legal Vision of Toxic Causation for the Post-Genomic Era, 70 WASH. \& LEE L. REV. 237, 251 (2013) (discussing standards of evidentiary proof in the context of toxic torts).

47. David S. Moore, The Basic Practice of Statistics 262 (5th ed. 2010) (explaining that "chance behavior is unpredictable in the short run but has a regular and predictable pattern in the long run").

48. Id. at 267. 
red marbles; the marbles are otherwise identical. A player must reach into the vase and draw five marbles out without looking to see what color they are. Assuming that we know, ex ante, the contents of the vase, then we know that only specific outcomes are possible. The player might draw five blue marbles, but she certainly won't draw five green marbles. We can also make more detailed predictions of possible outcomes. For example, the chance of drawing five blue marbles is quite low, and the chance of drawing five red marbles is reasonably high. The result is thus probabilistic: We don't know for certain what's going to happen, but we have a pretty good idea about what's probably going to happen.

\section{B. Patent Rights as Probabilistic Rights}

The idea that patent rights are probabilistic is one that has gained traction in recent years ${ }^{49}$ and is fairly well accepted today.$^{50} \mathrm{In}$ their 2005 work, Probabilistic Patents, Mark Lemley and Carl Shapiro identified two dimensions of uncertainty: "1) uncertainty about the commercial significance of the invention being patented, and 2) uncertainty about the validity and scope of the legal right

49. Lemley \& Shapiro, supra note 12, at 75. Lemley and Shapiro's work represents a move towards formalizing the longstanding understanding that patent rights (like many other forms of rights) involve some degree of uncertainty. See, e.g., Wm. Redin Woodward, Folk: Patents and Industrial Progress, 56 Harv. L. Rev. 672, 675 (1943) (reviewing George E. Folk, Patents And Industrial PROGRESS (1942)) (referring to the "'uncertainty principle' resulting from the fact that the grant of a patent, as a decision on novelty and inventiveness, is tentative to a degree not true of most other administrative and judicial decisions"); Case Comment, Costs of Patent Infringement Litigation May Be Expensed, 103 U. PA. L. REV. 975, 978 (1955) ("The complexity of many patents and the difficulty frequently encountered in tracing and determining the "prior art' result in uncertainty and invite controversy regarding the permissible bounds of many patent claims." (footnote omitted)); Gretchen Ann Bender, Uncertainty and Unpredictability in Patent Litigation: The Time is Ripe for a Consistent Claim Construction Methodology, 8 J. InTELL. Prop. L. 175, 175 (2001); Ian Ayres \& Paul Klemperer, Limiting Patentees' Market Power Without Reducing Innovation Incentives: The Perverse Benefits of Uncertainty and Non-Injunctive Remedies, 97 Mich. L. REV. 985, 987 (1999). In addition to recognizing the uncertainty present in asserting a patent (indeed, their argument is that certain types of this uncertainty may actually be economically beneficial), Ayres and Klemperer introduce a reductive "probabilistic patent" regime to model the consequences of this uncertainty. Id.

50. See, e.g., Ted Sichelman, Why Barring Settlement Bars Legitimate Suits: A Reply to Rosenberg and Shavell, 18 CoRnell J. L. \& PuB. Pol'y 57, 81 (2008) (referring to the "probability of success" of winning a patent lawsuit). 
being granted." ${ }^{51}$ Given these uncertainties, Lemley and Shapiro describe patents as "lottery tickets": "Inventors who are uncertain of the commercial significance of their ideas seek to patent many of them anyway, knowing that most of the resulting patents will turn out to be worthless, but hoping that a few will pay off big-time." ${ }^{52}$

For purposes of understanding the legal rights that patents embody, however, it is important to distinguish between the two uncertainties that Lemley and Shapiro identify. While commercial significance is an important consideration when weighing the effect of a patent, it is the second form of uncertainty that they point touncertainty about the validity and scope of the legal right- that most directly implicates the idea that patent rights can be probabilistic. ${ }^{53}$

This probabilistic nature of patent rights involves uncertainties at a number of points. Each patent claim gives the patent owner the exclusive right to make, use, offer for sale, or sell within the United States or import into the United States the invention, ${ }^{54}$ which the law has long held to mean the invention as defined by the claims. ${ }^{55}$ The patent applicant (or in most cases, the applicant's attorney) drafts the claims and proposes them to a patent examiner, who reviews them for various patentability requirements. ${ }^{56}$ The examiner issues the patent with its claims if all substantive and procedural requirements are met. $^{57}$

51. Lemley \& Shapiro, supra note 12, at 76.

52. Id. at 81 .

53. Indeed, Lemley and Shapiro expressly refer to the "legal right" with this form of uncertainty. See id. at 76.

54. 35 U.S.C. $\S \S 154(a)(1), 271(a)$ (2012). There are other statutorily specified acts of infringement, but for purposes of the discussion these will suffice.

55. Phillips v. AWH Corp., 415 F.3d 1303, 1312 (2005) (en banc) (noting the "'bedrock principle' of patent law that 'the claims of a patent define the invention to which the patentee is entitled the right to exclude' ... [which] has been recognized since at least 1836" (citations omitted)); see also Markman v. Westview, F.3d 967, 980 (Fed. Cir. 1995) ("The written description part of the specification itself does not delimit the right to exclude. That is the function and purpose of claims."); Lighting Ballast Control LLC v. Philips Elecs. N. Am. Corp., 744 F.3d 1272, 1284 (Fed. Cir. 2014) (en banc) ("Claim construction is a legal statement of the scope of the patent right [that turns on] the content of the patent documents.").

56. See generally NARD, supra note 28, at 39-49 (detailing the process of obtaining a patent).

57. See MPEP ch. 2100 (9th ed. Mar. 2014); see also NARD, supra note 28, at 45 . 
This process is hardly perfect; indeed, it is unlikely that it ever could be. ${ }^{58}$ Each year the patent office grants hundreds of thousands of patents containing multiple claims. ${ }^{59}$ Each examiner spends, on average, fewer than twenty hours examining a patent. ${ }^{60}$ And while examiners can competently handle some aspects of the examination process, ${ }^{61}$ other aspects can be more challenging, such as areas where the law is in flux, ${ }^{62}$ areas where guidance only exists as high level, ${ }^{63}$

58. See Mark A. Lemley, Rational Ignorance at the Patent Office, $95 \mathrm{Nw}$. U. L. REV. 1495, 1497 (2001) ("Because so few patents are ever asserted against a competitor, it is much cheaper for society to make detailed validity determinations in those few cases than to invest additional resources examining patents that will never be heard from again. In short, the PTO doesn't do a very detailed job of examining patents, but we probably don't want it to.").

59. U.S. Patent Statistics Chart Calendar Years 1963-2013, U.S. PAT. \& TRADEMARK OFF., http://www.uspto.gov/web/offices/ac/ido/oeip/taf/us_stat.htm (last visited Sept. 18, 2015).

60. Dan L. Burk \& Mark A. Lemley, The Patent Crisis and How the Courts Can Solve It 15 (2009). This amount goes down as examiners become more senior. See Mark A. Lemley \& Bhaven Sampat, Examiner Characteristics and Patent Office Outcomes, 94 ReV. ECON. \& STATs. 817, 817 (2012); see also Michael Frakes \& Melissa F. Wasserman, Does the U.S. Patent \& Trademark Office Grant Too Many Bad Patents?: Evidence from a Quasi-Experiment, 67 STAN. L. REV. 613, 669 (proposing reasons that senior examiners spend less time per application than junior examiners). In addition, Wasserman and Frakes found the reduction in time offset any increase in examining ability due to greater experience. Id.

61. In particular, the compliance with certain technical requirements of claim drafting such as the requirement for antecedent basis. MPEP $\S 2173.05(\mathrm{e})$ (9th ed. Mar. 2014) (describing how a claim is indefinite due to lack of antecedent basis and how an examiner should correct it); see also id. $§ 2173.05$ (providing a list of technical issues frequently raised in examination process and guidance to resolve them).

62. Such as patent-eligible subject matter. See, e.g., Ass'n for Molecular Pathology v. U.S. Patent \& Trademark Office, 689 F.3d 1303, 1337 (Fed. Cir. 2012) (overturning the district court's summary judgment granted to the Patent Office that held isolated DNA was ineligible subject matter), aff'd in part, rev'd in part sub nom. Ass'n for Molecular Pathology v. Myriad Genetics, Inc., 133 S. Ct. 2107 (2013) (holding synthetically created cDNA patent eligible subject matter); see also In re Bilski, 545 F.3d 943, 950, 966 (Fed. Cir. 2008) (en banc) (affirming the Patent Office's decision to reject a business method patent application but "conclud[ing] that the 'useful, concrete and tangible result' inquiry is inadequate and reaffirm[ing] that the machine-or-transformation test outlined by the Supreme Court is the proper test to apply), aff'd on other grounds sub nom. Bilski v. Kappos, 561 U.S. 593 (2010) (affirming the patent rejection but holding "[t]he Court of Appeals incorrectly concluded that this Court has endorsed the machine-or-transformation test as the exclusive test"); Application of Bergy, 596 F.2d 952, 987 (C.C.P.A. 1979) (overturning the Patent Office's decision that manmade, genetically engineered bacterium is not patent eligible), aff'd sub nom. Diamond v. Chakrabarty, 447 U.S. 303 (1980). 
searches for nonpatent prior art, and possibly novel strategic behaviors for seeking broad claim scope ${ }^{64}$ No one seriously contends that the patent office gets it right all the time. We know that at least some patents are invalidated by the courts ${ }^{65}$ which logically are in a better position to assess the true validity and scope of the patent due to superior information and a longer time to ponder the issues. ${ }^{66}$

The result is that a patent claim, when it issues, may or may not actually be valid. To be sure, it is imbued with a presumption of validity, ${ }^{67}$ but that is only a presumption, not an incontestable proposition. To figure out whether a patent claim is really valid requires a substantial undertaking; and even then, one can never be certain. A court might reject patent invalidity in one suit, but another court might reach the opposite result. ${ }^{68}$ Furthermore, validity is measured in several dimensions: newness (novelty and

63. Such as patent-eligible subject matter. See, e.g., Interim Guidance for Determining Subject Matter Eligibility for Process Claims in View of Bilski v. Kappos, U.S. PAT. \& TRADEMARK OFF., http://www.uspto.gov/patents/announce/ bilski guidance.jsp (last visited Sept. 18, 2015) (follow hyperlinks under the "July 27, 2010 Memorandum to the Examining Corps" and "101 Method Eligibility Quick Reference Sheet").

64. Such as the rise of functional claiming. Dennis Crouch, Functional Claim Language in Issued Patents, PATENTLY-O, http://patentlyo.com/patent/ 2014/01/functional-language-patents.html (last visited Sept. 18, 2015) (reporting an increase of certain types of language associated with claiming function in issued patents despite a decrease in means-plus-function claims); see generally Mark A. Lemley, Software Patents and the Return of Functional Claiming, 2013 Wis. L. REV. 905 (2013).

65. John R. Allison, Mark. A. Lemley \& David L. Schwartz, Understanding the Realities of Modern Patent Litigation, 92 Tex. L. Rev. 1769, 1801 (2014) (reporting a litigation invalidation rate of $43 \%$ during the study period).

66. See Lemley, supra note 58, at 1513 (comparing the amount of time available to the patent office and the courts when making determinations about a patent). Of course, it may be that patent examiners are in the better position to reach a "true" determination of validity given their firsthand technical expertise, something that courts and juries typically do not possess.

67. 35 U.S.C. § 282(a) (2012) ("A patent shall be presumed valid. Each claim of a patent (whether in independent, dependent, or multiple dependent form) shall be presumed valid independently of the validity of other claims; dependent or multiple dependent claims shall be presumed valid even though dependent upon an invalid claim.").

68. Compare Univ. of Ill. Found. v. Winegard Co., 402 F.2d 125, 129 (8th Cir. 1968) (holding the patent No. 3,210,767 invalid as obvious), with Univ. of Ill. Found. v. Blonder-Tongue Labs., 422 F.2d 769, 778 (7th Cir. 1970) (holding patent No. 3,210,767 not invalid), vacated, 402 U.S. 313, 350 (1971). 
nonobviousness), adequate disclosure (enablement and written description), utility, and subject matter eligibility. ${ }^{69}$

Uncertainties over defining the claim scope add to the probabilistic nature of patent rights. ${ }^{70}$ Claim construction is one of the most volatile aspects of patent law, and entire forests of paper and oceans of ink have been dedicated to its cause. ${ }^{71}$ The Federal Circuit has issued four en banc opinions on claim construction in the last twenty years ${ }^{72}$ and claim construction remains one of (if not the) most central issues in nearly all patent infringement disputes. ${ }^{73}$ There are many reasons why this is so ${ }^{74}$ but suffice it to say that

69. For example, "[t]he laws of nature, physical phenomena, and abstract ideas have been held not patentable." Diamond v. Chakrabarty, 447 U.S. 303, 309 (1980).

70. This might be more precisely described as a form of indeterminacy rather than of probability, but regardless of the precise articulation, what is important for purposes of this paper is simply that the idea that patent scopes can be uncertain for reasons beyond the parties' immediate control. For my comment on the indeterminacy-probabilistic distinction, see supra notes 12-15 and accompanying text.

71. See, e.g., NARD, supra note 28, at 512-17 (discussing practical issues of claim construction and listing scholars who have commented); see also Lighting Ballast Control LLC v. Philips Elecs. N. Am. Corp., 744 F.3d 1272, 1296 (Fed. Cir. 2014) (en banc) (O'Malley, J., dissenting) ("Criticism of and debate over Cybor have been widespread since it issued - not only among legal scholars and patent practitioners, but also among members of this court.").

72. Id. at 1276; Phillips v. AWH Corp., 415 F.3d 1303, 1310 (2005) (en banc); Cybor Corp. v. FAS Techs., Inc., 138 F.3d 1448, 1451 (Fed. Cir. 1998) (en banc); Markman v. Westview Instruments, Inc., 52 F.3d 967, 970 (Fed. Cir. 1995) (en banc). And despite the Supreme Court's recent holding in Teva v. Sandoz that "subsidiary facts" in claim construction are entitled to deference by the Federal Circuit, the Federal Circuit's approach to reviewing claim construction remains largely unchanged. See Jason Rantanen, Fenner v. Cellco: Judge Newman Speaks on Claim Construction, PATENTLY-O (Feb. 15, 2015), http://patentlyo.com/patent/ 2015/02/fenner-speaks-construction.html.

73. NARD, supra note 28 , at $61 \&$ n.7 ("[I]n the context of litigation, once claims are interpreted, issues of validity and infringement are largely foregone conclusions.").

74. For a discussion of why claim construction remains a challenging enterprise, see Jason Rantanen, Reading Patent Law: A Review of Reading Law: The Interpretation of Legal Texts, 6 LANDSLIDE 50, $52-53$ (2013) (book review). For another perspective on why claim construction is so volatile, see Tun-Jen Chiang \& Lawrence B. Solum, The Interpretation-Construction Distinction in Patent Law, 123 YALE L. J. 530, 533-35 (2013) (arguing that the uncertainty in how claims are applied is due to policy disagreements about the underlying goals of claim construction as opposed to ambiguous language). 
uncertainties over the meaning of claim terms add yet more uncertainty to the probabilistic nature of patent rights. ${ }^{75}$

Many of these uncertainties flow from incomplete information: incomplete information about what prior art might be out there and incomplete information about how particular words might be interpreted by a person of skill in the relevant technological art. Incomplete information also stems from uncertainties over the technological makeup of the infringing product itself. But uncertainty involves more than imperfect information. Many issues in patent law involve not only what the information is, but also how it is analyzed in conjunction with the patent. ${ }^{76}$ Decision-makers can differ, for example, on issues of claim construction even when looking at the same evidence. ${ }^{77}$ In the end, patents involve questions to which it is impossible to know answers with absolute certainty. ${ }^{78}$

The idea of patents as being probabilistic, then, is one that cannot be seriously disputed from a practical perspective. ${ }^{79}$ Patents

75. Alan Devlin, Indeterminism and the Property-Patent Equation, 28 YALE L. \& POL'Y REV. 61, 75-80 (2009) (explaining that claim terms' indeterminate scope contributes to uncertainty).

76. There is a view that how decision-makers will decide particular questions is a form of information, too. See, e.g., Sichelman, supra note 50, at 81 (observing that "the probability of success is a continuous function that becomes more accurate over the course of a case"). And I agree that it can certainly be viewed that way. But thinking of analytical reasoning as a form of information takes us down the rabbit hole into a world where everything is just information, a fall that doesn't provide much useful structure to grasp. For this reason, I think that it's conceptually helpful to differentiate between information about what evidence is out there and information about a particular judge's analytical preferences. And, curiously, there is an unquestionably probabilistic component here: District judges, it turns out, are usually randomly assigned to cases. The majority of courts use some variation of a random drawing. See FAQs: Filing a Case, U.S. CourTs, http://www.uscourts.gov/faqs-filing-case (last visited Sept. 18, 2015) (explaining that, in assigning judges to cases, "[t]he majority of courts use some variation of a random drawing"). And so which decision-maker will actually get a given case is inherently probabilistic.

77. See, e.g., GE Lighting Sols., LLC v. AgiLight, Inc., 750 F.3d 1304, 1315 (Fed. Cir. 2014) (Reyna, J., concurring in part and dissenting in part) (disagreeing as to the interpretation of the claim terms "substantially ellipsoidal inner profile"" and "'generally spherical outer profile"").

78. See Sichelman, supra note 50, at 81-88.

79. Although one could take the epistemological position that there is an "absolute truth" of the validity and scope of patents, the existence of such an absolute truth only matters if humans are in a position to arrive at it. But, unfortunately perhaps, we as human beings are limited by our human perception and understanding. Thus, to the extent there is an absolute truth, that absolute truth is irrelevant. The best we can do is make a probabilistic assessment of that truth. 
are now well understood as involving highly variable rightsprobabilistic rights - that may or may not be valid, and whose degree of validity is not known with certainty. ${ }^{80}$ In contrasting patent rights with traditional property rights, for example, Alan Devlin observes that " $[t]$ he world of patent law is different. For those unfamiliar with the nature of prosecution at the Patent and Trademark Office ... and the reality of patent litigation, the level of uncertainty underlying such intellectual property rights is astonishing." 1

Patent rights can even be extended beyond the literal scope of the claims, although this is marshy ground. The doctrinal mechanism involved is the "doctrine of equivalents," which "protects [the patentee] against efforts of copyists to evade liability for infringement by making only insubstantial changes to a patented invention." 82 Application of the doctrine of equivalents is a complex area of patent law, with numerous limitations ${ }^{83}$ and substantial uncertainties. ${ }^{84}$ But it lends yet more variability to the already highly uncertain nature of patent rights.

80. John W. Schlicher, Settlement of Patent Litigation And Disputes: Improving Decisions AND Agreements to SeTtTle AND LicEnSE 15-27 (2011) (outlining settlement models based on, in part, the probability a patent will be held invalid); Lemley \& Shapiro, supra note 12, at 80-87; see also EXECUTIVE Office of the President, PATENT Assertion AND U.S. InNOvation 4-6 (2013) [hereinafter "PRESIDENT's COUNCIL"], http://www.whitehouse.gov/sites/default/ files/docs/patent_report.pdf (noting that PAEs often acquire patents with unclear claim boundaries); Devlin, supra note 75, at 75-80 (explaining how probabilistic validity contributes to uncertainty).

81. Devlin, supra note 75 , at 75.

82. Festo Corp. v. Shoketsu Kinzoku Kogyo Kabushiki Co., 535 U.S. 722, 727 (2002).

83. Warner-Jenkinson Co. v. Hilton Davis Chem. Co., 520 U.S. 17, 26-41 (1997) (affirming the doctrine of prosecution history estoppel and holding that the doctrine of equivalents "be applied to individual elements of a claim, not to the invention as a whole" and not be "allowed such broad play as to effectively eliminate that element in its entirety").

84. Festo, 535 U.S. at 727 ("[W]e appreciated that by extending protection beyond the literal terms in a patent the doctrine of equivalents can create substantial uncertainty about where the patent monopoly ends. If the range of equivalents is unclear, competitors may be unable to determine what is a permitted alternative to a patented invention and what is an infringing equivalent." (citations omitted)). As one example, in 2007, John Allison and Mark Lemley wrote an article entitled The (Unnoticed) Demise of the Doctrine of Equivalents, which reported empirical data indicating that the doctrine of equivalents was near death, and equivalents claims usually failed. 59 STAN. L. REV. 955, 958 (2007). Yet, as of 2013, patent owners still experience some success with the doctrine of equivalents. Dennis Crouch, Doctrine of Equivalents: On the Rise Again?, PATENTLY-O (Feb. 21, 2013), http://patentlyo.com/patent/2013/02/doctrine-of-equivalents-on-the-rise.html. 
All of these discussions about the probabilistic nature of patent rights, however, come from the perspective of those rights as fixed. Consider, for example, the common analogy of patent rights to lottery tickets. ${ }^{85}$ When one buys a lottery ticket, one has a certain probability of winning. That ticket gives the holder a probabilistic right to win. The ticket owner can do nothing to alter that probability. Indeed, the only strategies for enhancing one's chances of winning are to buy more tickets ${ }^{86}$ or join a lottery pool. ${ }^{87}$ That right is thus probabilistic, but fixed.

Unlike the owner of a lottery ticket, however, a patent holder has the ability to actually change the probabilities in its favor. ${ }^{88}$ At its most extreme, consider the following: A patent in the hands of most people is simply a fancy piece of paper, perhaps with some technical information in it. But in the hands of the right person - a patent litigator, for example - that patent becomes a potent weapon of exclusionary rights. That right is not fixed; it is malleable.

\section{FIXED VERSUS MALLEABLE}

\section{A. The Concept of Malleability}

Malleability refers to a different idea than probability. A malleable right is one that can be altered after it has come into existence. The right is not fixed, but rather can be changed in some meaningful way.

To illustrate how rules can be malleable, we can alter the bluemarble example given above by giving the player the option of drawing fewer or more than five marbles. We can now say that the rule requiring the player to draw five marbles is malleable. If the goal of the game is to draw five blue marbles, the player will choose to draw 100 marbles, thus ensuring that she draws the five blue marbles. On the other hand, if the goal is to draw no blue marbles, the player will choose to draw no marbles at all. It should be apparent from this example that malleability can give a great deal of power to those who can take advantage: Depending on the game's

85. Lemley \& Shapiro, supra note 12 , at $80-83$.

86. Which from a rational perspective is a poor strategy, since the riskadjusted value of winning doesn't change if you buy more lottery tickets.

87. This doesn't change the risk-adjusted value of winning either.

88. I give this perspective for the sake of illustration only. Equally important, as I discuss below, is the ability of an accused infringer or other patent challenger to push inward on the patent scope or validity of a patent. 
goal, the player's ability to modify the draw rule could result in an automatic win or loss. ${ }^{89}$

Malleability need not be complete to be potent, either. Even if the player's ability to modify the draw rule is constrained (for example, the player may choose how many marbles to draw, but must draw at least one and may draw no more than ten), the player has a substantial advantage over another player who is forced to draw a fixed number of marbles.

In understanding the concept of malleability, it is important to understand what it does not mean. First, malleability does not encompass private modifications of rights among two or more parties with respect to one another. Such changes occur constantly through contract: One party agrees to perform or abstain from performing some act in return for the other party performing or abstaining from performing some act of its own. ${ }^{90}$ Private modifications of rights may change the legal relationship among the parties vis-à-vis one another, but they do not change the legal scope of those rights against the world. For example, a merchant may sell a particular good, say, a violin, to a buyer. In doing so, the merchant has transferred various rights relating to the violin to the buyer in return for, presumably, money. In this situation, the parties have indeed altered each other's respective legal positions: The buyer now has rights in the violin that are good against the world, and the seller no longer has such rights. Yet, what the parties have not done is change the legal scope of those rights with respect to the rest of the world. The parties cannot agree through this transaction, for example, that the buyer now has rights to all violins in the entire world. ${ }^{91}$ And while they can slice the transfer of rights in various ways (say, by leasing the violin rather than selling it), those rights still have the same form with respect to third parties. Upon leasing the violin, for example, the lessee has a right of possession that is good against the world. But no amount of agreement between the violin lessor and lessee can give the lessee

89. For true probability geeks, the best example is the Monty Hall problem, in which having the ability to switch doors after a losing door is opened raises one's chance of winning from $33 \%$ to $66 \%$. See Steve Selvin, Letters to the Editor: A Problem in Probability, 29 Am. Statistician 67-71 (1975); Steve Selvin, Letters to the Editor: On the Monty Hall Problem, 29 Am. Statistician 134, 134 (1975).

90. See Contract, Black's Law Dictionary (9th ed. 2009) (defining "contract" as "[a]n agreement between two or more parties creating obligations that are enforceable or otherwise recognizable at law").

91. Assuming, of course, that the seller does not actually have rights to all the violins in the world. 
permission to play in Carnegie Hall without the assent of the people who run Carnegie Hall.

Malleability, on the other hand, exists when legal rules that affect the world can be modified by individual actors. In the preceding example, if the violin seller were also a dictator with the power to change the rules about who was allowed to play where on a whim, we might say that those rules are malleable. This further illustrates a key difference between private modifications of rights and the concept of malleability: Malleability needs only the participation of one party. Put another way, a malleable right is one whose contours can be altered by a single actor operating by itself. ${ }^{92}$

Nor does malleability refer to the idea that legal rules can be changed by other legal rules. A statute can be amended by legislative action; it can be declared unconstitutional; its effect can be altered by regulations issued by an agency. A common law rule can be superseded by statute; it can be overruled by a higher court; it can be impacted by administrative action. These macro-level changes can affect the scope of individual rights. Consider, for example, the provision in the America Invents Act that, for all practical purposes, invalidated patents on tax evasion strategies. ${ }^{93}$ Such changes are not made by an actor operating within the legal system; they are made by an actor or actors operating on the legal system itself. It is thus not an example of malleability.

This is not to say that legal rules and changes to those legal rules cannot affect the degree to which rights may be malleable. To the contrary, the structure of a given set of legal rights can significantly impact the extent to which those rights are malleable. Patents, in particular, involve legal structures that tend to enhance their malleability.

92. As my colleague Paul Gowder pointed out, to the extent that high degrees of malleability are present in particular legal rights, it could have substantial implications for work on the rule of law. But such implications are well beyond the scope of this piece.

93. See Leahy-Smith America Invents Act, Pub. L. No. 112-29, § 14, 125 Stat. 284, 327 (2011) (stating that "[f]or purposes of evaluating an invention under section 102 or 103 of title 35, United States Code, any strategy for reducing, avoiding, or deferring tax liability, whether known or unknown at the time of the invention or application for patent, shall be deemed insufficient to differentiate a claimed invention from the prior art"). For a discussion of the AIA's impact on tax strategy patents, see Nichelle Closson, Tax Strategy Patents After the America Invents Act: The Need for Judicial Action, 38 J. CoRP. L. 159, 160 (2012). 


\section{B. Patent Rights as Malleable Rights}

Applying this understanding of malleability, when I say that patent rights are malleable, I mean that their scope and strength can be altered by actors interacting with those rights even after the government has issued that right. A patent owner is able to broaden the patent's scope after issuance or make it less likely to be declared invalid. And, on the other side, an accused infringer has the capacity to make the patent more likely invalid or diminish the possible scope of the patent; to shrink the effective space over which the patent grants a right to exclude. All of this occurs post-grant-in other words, once the patent right has been examined and comes into being as a legal right - and thus it is the right itself whose shape is being altered. This is the essence of malleability.

The next few Sections explain how the law permits patent scope to be adjusted after its grant. I begin by addressing the perception that patents are rights over discrete, disclosed "inventions." This view, I argue, is misguided. At best, patent rights can be perceived as being on an elastic leash tied to the technological disclosure of the patent. And that leash can stretch and contract even after the patent is issued. For example, claim meaning is not fixed in stone at the moment of patent issuance, but rather it can be pushed and pulled and altered by skillful argument. Nor is claim meaning the only boundary that parties can alter. The structure of patent claims themselves further enhances the malleability of patent rights, as do statutory rights of amendment post-grant. ${ }^{94}$

\section{The Elastic Leash on Patent Claims}

The perspective that patent rights are fixed often arises from the assumption that patent rights are rights over a discrete unit of

94. I have structured the following Sections in a way that highlights the ability of parties acting ex post to uncouple the scope of the claims from the technological disclosure of the patent. An alternative way to think about these Sections, however, is in terms of what the invention is. One view of the invention is that it is what the inventor invented as set out in the disclosure. See, e.g., Liivak, supra note 21, at 12-14; Timothy Holbrook, Possession in Patent Law, 59 SMU L. REv. 123, 128 (2011). A second view is that the claims define the invention. See Liivak, supra note 21, at 6-8. These divergent views lead to differing conceptions of the patent right as either the disclosure-as-invention or the claims-as-invention. The following sections demonstrate, however, that regardless of which way one views the patent right, the important point is that both incarnations are malleable. In other words, malleability does not depend on how one defines "the invention." 
technology-typically characterized as the technological teachings of the patent document itself - that was either invented by the inventor and then appropriated, perhaps unfairly, or was independently invented by another. ${ }^{95}$

Richard Epstein's approach to patents presents a strong example of this perspective. Epstein's view treats patents as modular units that are, in many ways, akin to tangible property. ${ }^{96}$ Patents are not simply exclusive rights, but are more like mutually exclusive rights: rivalrous with respect to other patents and the public domain. Put another way, allowing an invention to be patented takes nothing away from what the public already has. The patent merely grants a right over something new that the public did not previously have access to. To analogize, if one magically transforms a one-acre common field to a two-acre field, then granting the creator an exclusive right to that new acre takes nothing away from anyone else. Rather, it gives the public access to something new that would not exist but for the patentee's act.

95. As an example, see Peter Detkin's story of Dr. Cunningham, which I discuss in more detail in Jason Rantanen, How Malleability Matters, IP THEORY (forthcoming), http://ssrn.com/abstract=2623711. A central point in that story is that "[i]n a perfect world Dr. Cunningham would be compensated for his time, talent, and investment; the manufacturers would get a technology to advance their business; and the public would get better computers." Peter N. Detkin, Leveling the Playing Field, 6 J. Marshall Rev. Intell. Prop. L. 636, 639 (2007). Patents and their underlying technology are tightly linked in this narrative. As another example, consider Patrick Ennis's blog post at Intellectual Ventures (IV) entitled Patents are Recipes, Not Monopolies, on Invention, in which he comments that "[i]t's important to remember that patents only confer the right to exclude others from using your exact invention." Patrick Ennis, Patents Are Recipes, Not Monopolies, on Invention, INTELL. VENTURES (Nov. 18, 2013), http://www.intellectualventures.com/ insights/archives/patents-recipes-not-monopolies-on-invention. This is not to suggest that IV is the only entity making such a move; conflation of the technology with the patent rights itself is a key move in all efficient invention narratives.

96. Such a thread runs through much of Professor Epstein's views about the patent system, from business method patents to pharmaceuticals to software. See Richard A. Epstein, Trolling for "Patent Trolls", Hoover Institution (June 11, 2013), http://www.hoover.org/research/trolling-patent-trolls; Rod Cooper, Richard A. Epstein, \& Stephen Haber, Patent Nonsense, Hoover Institution (Jan. 25, 2013), http://www.hoover.org/publications/hoover-digest/article/138511; IIT Chicago-Kent College of Law, Debate About the Patent System, YouTuBe (May 1, 2013), https://www.youtube.com/watch?v=AYLyXJTE2aI (beginning at about 35 minutes); Richard A. Epstein, The Property Rights Movement and Intellectual Property, 30 REg. 58, 62 (2008). This is not to say that Epstein's view is that patents and land are exactly the same; but rather, that they are close enough for purposes of treating them in largely the same way. Nor is this to say that Epstein conceives of land in simplistic, Blackstonian terms - he clearly does not. See id. at 59. 
Consider the following example of a patent for a new transistor. ${ }^{97}$ The patent consists of a discrete package of information and rights surrounding this new transistor. If a radio manufacturer wants to legally employ this patented transistor in its products, it will find the inventor and negotiate a license. If, on the other hand, the improvement does not represent a significant commercial advantage over freely available alternatives, such as those for which patents have expired, then the manufacturer will not adopt the new technology. Even if the manufacturer independently develops the technology (but is second to do so and not entitled to patent rights), the manufacturer will either pay for the license once it becomes aware of the patent holder's rights or switch to the most economically efficient substitute. In this way, patents and technologies are equivalent. A patent is nothing more than a legal right over a specific new technology. ${ }^{98}$

As a second illustration, consider James McDonough III's argument in The Myth of the Patent Troll, in which he asserts that "the activities of patent dealers in their pure form benefit society." 99

97. Which, to be clear, is not from Professor Epstein himself, but is rather to illustrate my own interpretation of his view. See Jason Rantanen, PatCon 3: Posner/Epstein Debate on the Patent System, PAtently-O (Apr. 12, 2013), http://patentlyo.com/patent/2013/04/patcon-3-posnerepstein-debate-on-the-patentsystem.html.

98. That said, Professor Epstein's position does account for some malleability in the right that arises through the doctrine of equivalents. Indeed, he commented to me that the doctrine of equivalents plays a key role in his view because "it deals with the risk of circumvention of the patent by strategic substitution that comes from imitation and variation and not independent variance." See also Richard A. Epstein, Reflections on the Historical Origins and Economic Structure of the Law Merchant, 5 CHI. J. INT'L L. 1, 13 (2004) (discussing the doctrine of equivalents). In other words, the doctrine of equivalents allows the patent right to encompass activities when copying is involved but excludes them when it is not. The patent right can sometimes stretch and sometimes not stretch. Indeed, the case law explicitly recognizes this potential for lawyer argument over copying affecting the application of the doctrine of equivalents and attempts to foreclose it. See Warner-Jenkinson Co. v. Hilton Davis Chem. Co., 520 U.S. 17, 36 (1997) ("The better view, and the one consistent with Graver Tank's predecessors and the objective approach to infringement, is that intent plays no role in the application of the doctrine of equivalents."). However, practical outcomes may tell another story. Cf. Christopher A. Cotropia \& Mark A. Lemley, Copying in Patent Law, 87 N.C. L. REV. 1421, 1452-54 (2009) (finding that allegations of copying are rare in patent infringement suits, even when willful infringement is raised).

99. James McDonough III, The Myth of the Patent Troll: An Alternative View of the Function of Patent Dealers in an Idea Economy, 56 EMORY L. J. 189, 204 (2006) (emphasis omitted). McDonough III's comment is significant because it 
His analysis conflates the patent right and the underlying technology. McDonough makes this move by directly linking "the invention" to the patent right:

This fact [the nonrivalrous nature of ideas] makes expropriation of the patent easy because another person can easily use an invention without the patent holder knowing. The patent system specifically attempts to ameliorate this problem by granting property entitlements in the innovation through excludability. ${ }^{100}$

Linking "the invention" to the patent right ("property entitlements" and "excludability") is critical to McDonough's thesis because it allows a shift from the general concept of a "market for ideas"101 to a "legitimate patent market," where "[p]atent dealers operate . . . by buying and licensing patents." 102 After all, the patent right simply secures the exclusive right to that particular invention, and given that linkage, it only makes sense that it can be bought and sold. ${ }^{10}$

Even those who are skeptical of such entities tend to treat the patent rights and "the invention"- that is, the technological disclosure of the patent - as equivalent. Consider Fiona ScottMorton and Carl Shapiro's articulation of patent assertion entities' (PAE) behavior:

An inventor has discovered and patented valuable technology .... She sells her patent to a PAE [patent assertion entity] that is skilled at finding downstream firms to whom the technology can be transferred. The PAE also is good at locating unscrupulous firms that have copied the patented technology and are using it without paying. ${ }^{104}$

Although their model recognizes that the goal of "PAEs is to enhance the monetization of the patents they acquire," 105 it implicitly

is one of, if not the, earliest sophisticated defenses of the emerging patent monetization strategies.

100. Id. at 206 (emphases added) (footnote omitted).

101. Id. at 204.

102. Id. at 207.

103. So compelling is this concept of an "invention marketplace" that as of early 2014, IV was including it as part of its primary self-identity. See This is What Creating an Invention Marketplace Looks Like, INTELL. VENTURES, http://www.intellectualventures.com/about/invention-marketplace (last visited Sept. 18, 2015). As with others, IV treats the patents and inventions as one and the same, which makes the marketplace concept seem even more logical.

104. Fiona Scott Morton \& Carl Shapiro, Strategic Patent Acquisitions 10 (Working Paper, 2013), http://papers.ssrn.com/sol3/papers.cfm?abstract_id= 2288911 (emphases added).

105. Id. at 14 . 
relies on a rigid connection between the invention and the scope of the patent rights themselves. ${ }^{106}$

$* * *$

The assumption that patent rights are merely rights over a specific technology draws upon an erroneous view of patent rights as merely being a fence around the technological disclosure of the patent. Either those rights are actually rights over the technological disclosure of the patent, or they are not (in which case the rights are invalid).

But it turns out patents are not merely the rights to embodiments of technologies. Rather, they are a set of exclusive rights that, while linked in some sense to a technological disclosure of an invention, are hardly just a set of plans for making and using that new invention that require payment to use. ${ }^{107}$ Nor are the exclusive rights conveyed by a patent limited to the specific embodiments that the patent discloses; to the contrary, patent rights are expressly not limited to these embodiments. ${ }^{108}$ And not only are patent rights not literally limited to the disclosure, but patent law has

106. The farthest that Morton and Shapiro move away from this assumption is in their observation that PAEs may do little or no technology transfer and conclude that the value of the technology may be greater than the value that the PAE can extract from the downstream firm. See id. "When the PAE takes a share of the downstream firm's profits that exceed the value of the licensed technology, the downstream firm's share of its own operating profits is necessarily reduced . ..." Id. Ultimately, however, this is not their primary focus (although in my view their model would be enhanced by including a parameter that accounts for the extent to which the PAE can expand the scope of the patent rights).

107. See, e.g., Johns Hopkins Univ. v. CellPro, Inc., 152 F.3d 1342, 1360-61 (Fed. Cir. 1998) (noting "“a considerable amount of experimentation"” to practice the patented invention is not fatal to the enablement requirement) (quoting PPG Indus., Inc. v. Guardian Indus. Corp., 75 F.3d 1558, 1564 (Fed. Cir. 1996))); Cedarapids, Inc. v. Nordberg, Inc., No. 95-1529, 1997 WL 452801, at*3 (Fed. Cir. Aug. 11, 1997) (noting "we have never held that a patent must disclose information sufficient to manufacture a commercial product incorporating the invention"); Jeanne C. Fromer, Patent Disclosure, 94 IowA L. REV. 539, 560-62 (2009) (noting a "good deal of evidence suggests that technologists do not find that [a patent document] contains pertinent information for their research").

108. Phillips v. AWH Corp., 415 F.3d 1303, 1320 (2005) (en banc) ("[O]ne of the cardinal sins of patent law [is] reading a limitation from the written description into the claims." (quoting SciMed Life Sys., Inc. v. Advanced Cardiovascular Sys., Inc., 242 F.3d 1337, 1340 (Fed. Cir. 2001))). Even if the claims are means-plus-function claims, their scope encompasses not just what is literally described in the specification, but also equivalents thereof. See 35 U.S.C. § 112(f) (2012). 
also developed doctrines that extend the scope of claims beyond even what they literally encompass. ${ }^{109}$

To be sure, patent law does contain a mechanism that seeks to maintain a link between the inventor's technological disclosure and the scope of the exclusive rights granted by the patent. ${ }^{110}$ And that requirement acts as a leash on the possible scope of claims. But it is merely a leash, not a fence; that leash often seems to be made of elastic rather than metal chains. ${ }^{111}$

The main ${ }^{112}$ patent law mechanism that ties the underlying invention to the scope of exclusive rights is comprised of a set of doctrines that can be collectively referred to as "'patent law's disclosure requirement." "113 These doctrines attempt to, among other things, ${ }^{114}$ ensure that the scope of the claims is commensurate with the inventor's technological disclosure in the patent. In practice, however, it turns out that actually applying the disclosure

109. See Festo Corp. v. Shoketsu Kinzoku Kogyo Kabushiki Co., 535 U.S. 722,732 (2002) ("The scope of a patent is not limited to its literal terms but instead embraces all equivalents to the claims described."); accord Graver Tank \& Mfg. Co. v. Linde Air Prods. Co., 339 U.S. 605, 608 (1950) (“"To temper unsparing logic and prevent an infringer from stealing the benefit of the invention' a patentee may invoke [the doctrine of equivalents] ... 'if it performs substantially the same function in substantially the same way to obtain the same result." (footnote omitted) (quoting Sanitary Refrigerator Co. v. Winters, 280 U.S. 30, 42 (1929))); Winans v. Denmead, 56 U.S. 330, 346 (1853) ("It is, that this court shall extend, by construction, the scope and operation of his patent, to embrace every form which in practice will yield a result substantially equal or approximate to his own.").

110. 35 U.S.C. $§ 112$ (a) (2012).

111. Compare Cedarapids, Inc., 1997 WL 452801, at *2 (concluding that a broad claim covering mechanical arts can be enabled by a disclosure of a single embodiment), with Auto. Techs. Int'l, Inc. v. BMW of N. Am., 501 F.3d 1274, 1285 (Fed. Cir. 2007) (concluding that a claim encompassing both electronic and mechanical sensors was not supported by the disclosure of only a mechanical sensor). Credit for this juxtaposition goes to NARD, supra note 28. See also Holbrook, supra note 94 (discussing the limitations of current disclosure doctrine).

112. I note that claim limitation might arguably be another mechanism for limiting the scope of patent claims to what has been disclosed, but that doctrine has evolved in a very different direction. Phillips, 415 F.3d at 1323 ("For instance, although the specification often describes very specific embodiments of the invention, we have repeatedly warned against confining the claims to those embodiments.").

113. Jason Rantanen, Patent Law's Disclosure Requirement, 45 LOY. U. CHI. L. J. 369, 371-75 (2013).

114. See id. at 373-74 (discussing purposes of patent law's disclosure requirement beyond commensurability). 
requirement is challenging from a technical, legal, and conceptual perspective; and there are rarely easy answers. ${ }^{115}$

In part, this is due to the general nature of the statute embodying the disclosure requirement. The text, 35 U.S.C. $§ 112(a)$, states:

The specification shall contain a written description of the invention, and of the manner and process of making and using it, in such full, clear, concise, and exact terms as to enable any person skilled in the art to which it pertains, or with which it is most nearly connected, to make and use the same.... 116

While this provision clearly requires information about how to make and use the invention, it does not necessitate (nor has it been interpreted to require) disclosure of every possible permutation of the invention. ${ }^{117}$ Rather, a person of skill in the art is expected to bring his or her knowledge to bear, ${ }^{118}$ and even then, some experimentation (although not undue experimentation) is allowed. ${ }^{119}$ As a result, the enablement inquiry is flexible, sometimes turning on the knowledge and skills of a person of skill in the art, ${ }^{120}$ sometimes turning on whether the experimentation required is undue, ${ }^{121}$ and sometimes turning on yet other legal issues. ${ }^{122}$ Similarly, the written description

115. See Chiang, supra note 15, at 537 ("If obviousness is the most nebulous concept in patent law, then enablement and written description is a close second.").

116. 35 U.S.C. $§ 112$ (a) (2012).

117. See NARD, supra note 28, at 107 ("Patent law does permit applicants to claim generically without disclosing each and every species as long as the disclosure is sufficient."). Disclosure doctrine scholarship that influences my description of how the doctrine actually works includes Holbrook, supra note 94; Sean B. Seymore, The Teaching Function of Patents, 85 Notre Dame L. ReV. 621 (2010); Jeanne C. Fromer, Patent Disclosure, 94 IowA L. REV. 539 (2009); Lisa Larrimore Ouellette, Do Patents Disclose Useful Information?, 25 HARV. J.L. \& TECH. 545 (2012); see also Rantanen, supra note 113.

118. See Hybritech Inc. v. Monoclonal Antibodies, Inc., 802 F.2d 1367, 1384 (Fed. Cir. 1986).

119. See, e.g., Atlas Powder Co. v. E.I. Du Pont de Nemours \& Co., 750 F.2d 1569, 1576 (Fed. Cir. 1984).

120. Genentech, Inc. v. Novo Nordisk, 108 F.3d 1361, 1366 (Fed. Cir. 1997).

121. See, e.g., Cedarapids, Inc. v. Nordberg, Inc., No. 95-1529, 1997 WL 452801, at *2 (Fed. Cir. Aug. 11, 1997). Nor is it a simple matter to determine how much experimentation is "undue": Answering this question turns out to be quite a challenge.

122. Such as the "full scope" tension, which I will not get into here. Compare Liebel-Flarsheim, Co. v. Medrad, Inc., 481 F.3d 1371, 1380 (Fed. Cir. 2007) ("[A]s part of the quid pro quo of the patent bargain, the applicant's specification must enable one of ordinary skill in the art to practice the full scope of the claimed invention." (quoting AK Steel Corp. v. Sollac \& Ugine, 344 F.3d 1234, 
requirement imposes a limited constraint on the permissible boundaries of the claims: Its role is fairly circumscribed outside the context of biotechnology. ${ }^{123}$

In addition, it is a fundamental principle of patent law that an inventor is not limited to only the embodiments disclosed in the specification. As Donald Chisum observes: "An enabling disclosure is all that is required. The applicant need not describe actual embodiments or examples. Indeed, an applicant need not have reduced the invention to practice prior to filing." 124

This legal structure allows an inventor to claim broadly, with only a limited constraint imposed by the enablement and written description doctrines. Oskar Liivak, in Rescuing Invention from the Cult of the Claim, for example, notes the widely held view that "[c]laims are frequently a far cry from what the inventor invented." 125

This is not to say that patent law's disclosure requirements have no teeth. To the contrary, patent claims are invalidated for extending beyond what the enablement and written description requirements allow. ${ }^{126}$ Yet, what one person might see as an enabled claim another might not. ${ }^{127}$ The point is not that there are no boundaries at all. Rather, the point is that the law on enablement and written description permits claiming beyond what is contained in the patent's technological disclosure. Nor does the law lend itself to easy determinations. As one text put it:

Regrettably, no precise equation allows us to determine whether a particular patent claim suffers from "undue breadth" in view of the

1244 (Fed. Cir. 2003))), with Edwards Lifesciences AG v. CoreValve, Inc., 699 F.3d 1305, 1309 (Fed. Cir. 2012) ("Precedent establishes that ' $\mathrm{t}]$ he enablement requirement is met if the description enables any mode of making and using the invention." (quoting Johns Hopkins Univ. v. CellPro, Inc., 152 F.3d 1342, 1361 (Fed. Cir. 1998) (emphasis added))).

123. See Liivak, supra note 21 , at 13 (describing the conventional view of the invention).

124. Donald S. Chisum, Chisum on Patents § 7.03 (2014) (citation omitted).

125. Liivak, supra note 21 , at 15 (quoting Judge Giles S. Rich in JANICE Mueller, PATENT LAW 67 (3d ed. 2009)). Liivak, of course, was making this observation in the context of rebutting it, arguing that the proper way to conceive of the scope of rights is through the lens of invention, not claims. Id.

126. See, e.g., Ariad Pharms., Inc. v. Eli Lilly \& Co., 598 F.3d 1336, 1358 (Fed. Cir. 2010) (en banc) (invalidating patent claims for lack of written description).

127. See, e.g., Union Carbide Chems. \& Plastics Tech. Corp. v. Shell Oil Co., 308 F.3d 1167, 1191-93 (Fed. Cir. 2002) (Mayer, C.J., dissenting) (disagreeing with the majority's holding on enablement). 
disclosure of the patent's specification. . . . As informed by the Wands factors, the enablement requirement provides a solid starting point, but unfortunately not an easily applied rule, for assessing when a particular patent claim exceeds its appropriate scope. ${ }^{128}$

The result is that the doctrines that embody the linkage between the technological disclosures of the patent and the claim scope are subject to stretching and contraction. ${ }^{129}$ Simply put, there is no doctrine in patent law that tightly limits the inventor's rights to precisely what she disclosed; at best, there is a bungee cord. One must still stay within the ballpark of the technology, but where in the ballpark tends to be the important question. ${ }^{130}$

128. Roger E. Schechter \& John R. Thomas, Principles of Patent LaW 188 (2d ed. 2004). Perhaps, one might argue, the problem is thus one of litigation costs: There is an answer, but it requires such a high investment to discover that in most instances is simply not feasible. Perhaps that is so. But my own experience is that when resources are invested into litigation in a symmetric manner, as is often the case in patent litigation, the issues become more complex rather than easier to resolve as more facts are uncovered and resourceful attorneys come up with clever arguments. See, e.g., Richard B. Phillips, Jr. \& Scott P. Stolley, Appellate Lawyers as Innovators, IN-House DEF. Q., 52-54 (2013) (describing the role of appellate lawyers in developing new ideas in a litigation). In any event, regardless of the cause, for all practical purposes enablement and written description often turn out to be very difficult issues to resolve and thus do not function as strong limitations on the maximum possible scope of claims.

129. Beyond the limitation on the disclosure requirement touched on above lies an even more complex and challenging puzzle for the enablement and written description requirements: How do they intersect with after-arising technology, that is, technological developments that emerge after the patent application is filed? The law in this area remains highly unsettled both doctrinally and theoretically, and thus adds yet additional kinks to the elastic leash on permissible claim scope. See, e.g., RoBin Feldman, Rethinking PATENT LAW 204 (2012) ("[T] he enablement doctrine is itself in disarray in terms of whether an inventor can reach things that could not have been known at the time of the invention."); see also Chiang, supra note 15, at 537-38 ("Enablement and written description therefore contain two directly contradictory lines of cases."); Morris, supra note 44, at 524 ("The courts expressly acknowledge [that the meaning of patent claims can change in unexpected ways] by requiring that claim language be interpreted by its meaning at different times, depending on whether the claim is being evaluated for obviousness, novelty, definiteness, infringement, enablement, and so on.").

130. Recognize that I am not taking a normative position here on whether the enablement and written description requirements should be a strong limit on the scope of claims or whether, as currently structured, they impose about the right level of constraint. Rather, I am simply pointing out that they do not presently function as an ironclad restraint. 


\section{The Game of Claim Construction}

Any elasticity in the disclosure requirement might not be such a concern if the actual scope of claims were fixed. Then, at least the boundaries of the patent right would be known to some degree. To be sure, there might still be some malleability over whether those boundaries are actually valid, that is, supported by adequate disclosure. But at least the boundaries themselves would be knowable, and potential infringers would know whether they were within those boundaries. ${ }^{131}$

But while this might be a normative aim, ${ }^{132}$ patent law does not actually work this way.

A better way to think about patent litigation-particularly claim construction - is as a sports game or contest. And like any good game, both skill and chance determine its outcome.

Take, for example, a baseball game. Picture a game in which the visiting team leads by a single run with two outs in the bottom of the ninth inning. ${ }^{133}$ An ace pitcher ${ }^{134}$ is on the mound. In hindsight, we can know that the ace pitcher will get the batter to make the final out, popping out to center field a few feet short of the wall, thus ending the game. ${ }^{135}$

Yet, as the events themselves play out, the outcome would be anything but certain. A gust of wind pushing the ball a few feet

131. See, e.g., James Bessen \& Michael J. Meurer, Patent Failure: How Judges, Bureaucrats, And Lawyers Put Innovators AT Risk 46-72 (2008) (arguing that patents do not provide effective notice of their scope); Christina Bohannan \& Herbert Hovenkamp, IP and Antitrust: Reformation and Harm, 51 B.C. L. REV. 905, 928-34 (2010) (discussing unclear boundaries in patents that do not create or transform physical objects).

132. Claim construction is "a way of elaborating the normally terse claim language in order to understand and explain, but not to change, the scope of the claims." Terlep v. Brinkmann Corp., 418 F.3d 1379, 1382 (Fed. Cir. 2005) (quoting Embrex, Inc. v. Serv. Eng'g Corp., 216 F.3d 1343, 1347 (Fed. Cir. 2000)).

133. Such as at the end of the 2014 World Series between the San Francisco Giants and the Kansas City Royals where, in the penultimate moment of the final game of the final series of the 2014 baseball season, the Giants led 3-2, with two outs in the bottom of the last inning. For those who don't follow baseball, this meant that if the Royals were to make one more "out," the Giants would win. On the other hand, if the Royals were to score once before making an "out," the game would continue on. And if the Royals were to score two runs before making an "out," the Royals would win the game, the series, and the championship.

134. Such as Madison Bumgarner.

135. For example, we know that the Giants won the 2014 World Series. E.g., David Waldstein, Three-Ring Master, N.Y. TimES, Oct. 30, 2014, at B14. 
farther could produce a completely different result. This is the external element of chance. But while chance is certainly an important component in baseball, even more central to the outcome are the abilities, the skills, the talent, and the other aspects of the players themselves and the choices they make. Perhaps all of the pitches that the pitcher threw were above the strike zone. Perhaps he made the conscious decision to throw the ball to that location because he knew that this particular batter would have a hard time hitting balls there. Another batter or another pitcher, and the game might come out another way.

The parallels between patent litigation and sport resonate deeply. Patent litigation is - just as sports are - a struggle to win. And while there are rules, those rules allow parties to have an effect on which party will prevail. ${ }^{136}$

It should be no surprise, then, that commentary on patent law is filled with references to litigation as a "contest,"137 a "sport," 138 and even as a "game." 139 And just like a contest, a sport, a game, patent

136. Added to this is the fact that the rules in patent law are, if anything, much less clear than the rules of baseball.

137. See, e.g., N. Scott Pierce, The Effect of the Leahy-Smith America Invents Act on Collaborative Research, 94 J. PAT. \& TRADEMARK OfF. SOC'Y 133, 134 (2012) (noting that the America Invents Act "replaces a statutory provision for a contest between patent applications, or between a patent application and a patent based on priority of inventorship"); Teresa Riordan, Contest Over BlackBerry Patent, N.Y. Times, (June 7, 2004), http://www.nytimes.com/2004/06/07/ technology/07patent.html (discussing a Federal Circuit trial involving Research in Motion and whether it "should be barred from doing business in the United States"); David Ward, David v Goliath Battle as Welsh Jeans Company Tells Levi's to Butt Out, The Guardian (May 1, 2003, 9:19 PM), http://www.theguardian.com/uk/ 2003/may/02/wales (reporting on "a contest being billed as San Francisco Bay versus Cardigan Bay").

138. Commentators have referred to patent litigation as "the sport of kings." See, e.g., James Bessen \& Michael J. Meurer, Lessons for Patent Policy from Empirical Research on Patent Litigation, 9 LEWIS \& Clark L. REV. 1, 2 (2005); Douglas J. Kline, Patent Litigation: The Sport of Kings, MIT Tech. ReV. (Apr. 28, 2004), http://www.technologyreview.com/business/13562/. While the emphasis is typically placed on the kings element (since the goal of the reference is typically to draw upon the idea that patent litigation is complicated and expensive), the reference to sport is also illuminating. In sports, some events are due to chance; much is also due to the skill of the individual players.

139. As Giles Rich said, "the name of the game is the claim." Giles S. Rich, Extent of Protection and Interpretation of Claims-American Perspectives, 21 INT'L Rev. Indus. Prop. \& Copyright L. 497, 499 (1990) (emphasis omitted); see also Function Media, L.L.C. v. Google Inc., 708 F.3d 1310, 1326 (Fed. Cir. 2013) ("Nearly every patent case will involve some amount of 'word games,' because claims and claim constructions are, after all, just words."); 3M Innovative Props. Co. 
litigation - and by extension, the patent right itself - is affected by the participants in that game.

Nowhere is this more true than in the claim construction game: ${ }^{140}$ the struggle between parties to get the court to adopt their interpretation of critical claim terms, terms on which the case will swing in favor of one side or another. Here, the patent right is at its most malleable. There is both substantial room for movement in claim scope, and the actions of the parties can affect that movement.

To understand why, first recall the uncertain outcome of claim construction, discussed above. Regardless of whether one views those uncertainties as being due to the ambiguities of language or policy conflicts, the key point is that patent claim language is, from both a practical and legal perspective, unstable prior to adjudication. ${ }^{141}$ There is thus room for movement because claim scope is hardly set in stone prior to adjudication. The "nose of wax" rhetorical device is exactly that: a rhetorical device. The practical reality is that claim meaning can be altered within limits after the patent has issued. ${ }^{142}$ Even setting aside broader disputes over word meanings, there can be disagreement over even which contextual principles of claim construction apply. Worse, as one commentator humorously noted, "[u]nfortunately, the 'canons' of patent claim interpretation sometimes 'fire' at cross purposes." ${ }^{143}$ By which he

v. Tredegar Corp., 725 F.3d 1315, 1335 (Fed. Cir. 2013) (Plager, J., concurring) ("Claim construction then becomes a game of crystal ball gazing, not resolved until this court's gaze is announced.").

140. A reference not to be confused with Edward D. Manzo's Claim Construction Game ${ }^{\circledR}$, which is an actual game designed to teach people about claim construction. THE CLAIM CONSTRUCTION GAME, Registration No. 3,621,447; see Edward David Manzo - Lawyer Profile, MARTINDALE, http://www.martindale.com/Edward-D-Manzo/43373648-lawyer.htm (last visited Sept. 18, 2015).

141. See Q-Pharma, Inc. v. Andrew Jergens Co., 360 F.3d 1295, 1301 (Fed. Cir. 2004) ("Claim interpretation is not always an exact science, and it is not unusual for parties to offer competing definitions of even the simplest claim language.").

142. Cf. Dan L. Burk, Patenting Speech, 79 Tex. L. Rev. 99, 147 (2000) ("Additionally, although courts in patent cases have some degree of latitude in claims interpretation, claims are not to be treated 'like a nose of wax which may be turned and twisted in any direction."' (quoting White v. Dunbar, 119 U.S. 47, 51 (1886))).

143. Edward D. Manzo, How to Improve Patent Claim Interpretations, 22 Fed. CIR. B. J. 203, 213 (2012). 
meant that these principles of interpretation can come into direct conflict with one another. ${ }^{144}$

Even once issued, a district court's claim construction is still not the final word on claim scope. Most significant is the prospect of change by the Federal Circuit. That the Federal Circuit reverses district court claim constructions is a point so fundamental that perhaps it need not be supported. ${ }^{145}$ One need not point to isolated anecdotal cases, either: The literature is full of empirical studies that specifically examine the rate at which the Federal Circuit reverses district courts on claim construction. ${ }^{146}$ While this rate has fallen in recent years, ${ }^{147}$ the Federal Circuit still modifies district court claim constructions and outright reverses them a meaningful portion of the time. ${ }^{148}$ Indeed, monitoring claim constructions is arguably one of its primary purposes. ${ }^{149}$

The point here is not only that two intelligent, rational minds can arrive at different claim constructions, but also that the patent right continues to be molded well after its construction by the district court through freshly presented arguments by counsel. The Federal Circuit does not just reverse district court judges who make only a

144. See id.

145. Krause and Auyang provide a host of examples. See, e.g., Thomas W. Krause \& Heather F. Auyang, What Close Cases and Reversals Reveal About Claim Construction at the Federal Circuit, 12 J. Marshall Rev. Intell. Prop. L. 583, 598-602, app. B (2013) (listing cases where the CAFC reversed the district court and narrowed or broadened claim terms).

146. See, e.g., Kimberly A. Moore, Are District Court Judges Equipped to Resolve Patent Cases?, 15 HARV. J.L. \& TeCh. 1, 15 (2001); David L. Schwartz, Courting Specialization: An Empirical Study of Claim Construction Comparing Patent Litigation Before Federal District Courts and the International Trade Commission, 50 WM. \& MARY L. REV. 1699, 1716 (2009); J. Jonas Anderson \& Peter S. Menell, Informal Deference: A Historical, Empirical, and Normative Analysis of Patent Claim Construction, 108 Nw. U. L. REV. 1, 39-41 (2013) (analyzing reversal rates since 2005 and finding reversal rates have decreased); Christopher A. Cotropia, Is Patent Claim Interpretation Review Deference or Correction Driven?, BYU L. REV. (forthcoming) (analyzing claim construction cases to determine whether "claim interpretation is still truly de novo and performed to correct lower court decisions (a) where patentees win and (b) especially where patents covering electronics, information technologies, and business methods succeed").

147. Anderson \& Menell, supra note 146, at 6 (finding the Federal Circuit's "reversal rate has dropped significantly since the Phillips decision").

148. Id.

149. See, e.g., Lighting Ballast Control LLC v. Philips Elecs. N. Am. Corp., 744 F.3d 1272, 1290 (Fed. Cir. 2014) (en banc) (arguing that reversal rates for claim construction have decreased since Cybor). 
passing effort at claim construction; it also reverses the claim construction of highly sophisticated patent judges with substantial patent law experience. ${ }^{150}$

Perhaps it is a matter of the Federal Circuit judges getting it "right" and the district court judge getting the claim construction "wrong." After all, three Federal Circuit judges sit on a reviewing panel, all of whom routinely review claim construction decisions.

But Federal Circuit judges frequently disagree among themselves when it comes to claim construction. ${ }^{151}$ Examples abound. Consider the court's recent decision in Azure Networks, LLC v. CSR PLC, which illustrates this disagreement. ${ }^{152}$ Judge Chen, joined by Judge Reyna, concluded that the district court erroneously construed the term "MAC address" in a particular patent claim. ${ }^{153}$ In their view, the correct construction of "MAC address" as used in the patent is "an address that uniquely identifies a device or group of devices on a shared communication medium." ${ }^{154}$ Writing in dissent, Judge Mayer would have construed the term as meaning "an address assigned to a peripheral device by a hub device." 155 Both constructions were clearly reasonable, as evidenced by the rational, logical arguments each opinion offered. ${ }^{156}$

District court judges, too, may alter their own claim constructions. Indeed, they may even depart from the Federal Circuit's own construction if that construction was only preliminary

150. See, e.g., Union Carbide Chems. \& Plastics Tech. Corp. v. Shell Oil Co., 308 F.3d 1167, 1167, 1177 (Fed. Cir. 2002) (overturning Chief Judge Sue L. Robinson's claim construction of "characterizable by an efficiency equation"); David L. Schwartz, Practice Makes Perfect? An Empirical Study of Claim Construction Reversal Rates in Patent Cases, 107 Mich. L. REv. 223, 256 (2008) (finding that "it does not appear that district judges' reversal rates decrease as they handle more patent cases").

151. See Krause \& Auyang, supra note 145, at 586-98, app. A (noting the "vast differences" among CAFC judges within a panel when construing claim terms and listing cases where dissenting or concurring opinions argued for broader or narrower claim terms' scope).

152. 771 F.3d 1336 (Fed. Cir. 2014).

153. See id. at $1337,1339$.

154. Id. at 1350.

155. Id. at 1353 (Mayer, J., dissenting).

156. Cf. id. at 1348-50, 1351-53 (Mayer, J., dissenting). Another example is Williamson v. Citrix Online, LLC, in which Judge Linn, joined by Judge Moore, agreed that the district court erroneously construed the term "distributed learning control module" as a means-plus-function expression while Judge Reyna would have affirmed the district court's construction. 770 F.3d 1371, 1373, 1380 (Fed. Cir. 2014). 
in nature. ${ }^{157}$ A district court judge may even adjust its claim construction after trial if that adjustment is merely an "elaboration." 158

But the above examples merely establish that claim meanings are not stable. Perhaps, the counterargument might be that claim construction is just a process of drawing colored marbles out of an urn. It's just a matter of randomness whether one draws a judge who likes your client's claim construction or a judge who dislikes your client's claim construction. This is a popular complaint: that claim construction is mostly a matter of chance. ${ }^{159}$

And yet, such a view that claim construction is merely unpredictable masks the underlying ability of parties to affect the outcome of that game. Consider the strongest form of the panel dependency argument, that is, the empirical evidence presented by

157. Outside the Box Innovations, LLC v. Travel Caddy, Inc., 695 F.3d 1285, 1302 (Fed. Cir. 2012) ("[A] claim construction reached during an appeal from a grant of preliminary injunction is tentative and is not binding . . . in subsequent proceedings" (quoting Transonic Sys., Inc. v. Non-Invasive Med. Techs. Corp., 75 F. App'x. 765, 774 (Fed. Cir. 2003))); see also Glaxo Grp. Ltd. v. Apotex, Inc., 376 F.3d 1339, 1346 (Fed. Cir. 2004) (“An appellate court's preliminary injunction opinion has no conclusive bearing at the trial on the merits and is not binding on a subsequent panel."); In re Papst Licensing Digital Camera Patent Litigation, 778 F.3d 1255, 1261 (Fed. Cir. 2015) ("For that reason, it is worth reiterating that a district court may (and sometimes must) revisit, alter, or supplement its claim constructions (subject to controlling appellate mandates) to the extent necessary to ensure that final constructions serve their purpose of genuinely clarifying the scope of claims for the finder of fact.").

158. Mformation Techs., Inc. v. Research in Motion Ltd., 764 F.3d 1392, 1397 (Fed. Cir. 2014) ("[W]e have allowed district courts in the past to adjust constructions post-trial if the court merely elaborates on a meaning inherent in the previous construction." (citing Cordis Corp. v. Boston Sci. Corp., 658 F.3d 1347, 1356 (Fed. Cir. 2011))). "Elaboration" is a tricky word; one party's "elaboration" can be another party's "modification."

159. See, e.g., Greg Reilly, Completing the Picture of Uncertain Patent Scope, 91 WASH. U. L. REV. 1353, 1359 (2014) ("Neither party can reliably predict the actual claim scope, which depends on the district judge's choice of methodological approach and (absent settlement) whether this choice is the same as that of two of the three judges on the Federal Circuit panel."); Kirk M. Hartung, Claim Construction: Another Matter of Chance and Confusion, 88 J. PAT. \& TRADEMARK OFF. SOC'Y 831, 831 (2006) ("Unfortunately, claim construction still is a matter of chance and confusion for patent owners, accused infringers and their patent attorneys. And the matter is only getting worse."); Petition for a Writ of Certiorari at 22, Hakim v. Cannon Avent Grp., PLC, 552 U.S. 951 (2007) (No. 07150) ("Perhaps the greatest problem facing the patent field today is the unpredictability of the Federal Circuit's approach to any given question of claim construction."). 
Lee Petherbridge and Polk Wagner of a split on the court between "proceduralist" and "holistic" judges. ${ }^{160}$ As Petherbridge and Wagner demonstrated in their 2006 study of claim construction, the approach a given judge follows will significantly affect the outcome of a claim construction. ${ }^{161}$ Two proceduralist judges on a panel will likely rule one way; two holistic judges, likely another.

Yet knowing this, effective advocates will adjust their positions to compensate. For example, one attorney observes another split in claim construction strategy: the invention versus words approach. ${ }^{162}$ "[U]se it to plan your advocacy in court. Judges' predilections are often well-known. Do the research and pitch your claim construction arguments to emphasise the approach that the judge has favoured in his prior claim construction rulings." ${ }^{163}$ While there is limited ability to do so in party briefs - the composition of the panel is not revealed to the public until the morning of oral argument ${ }^{164}$ - it is wellestablished among litigators that one would not, for example, argue a strong proceduralist position to, say, Judge Bryson. ${ }^{165}$

160. See, e.g., R. Polk Wagner \& Lee Petherbridge, Is the Federal Circuit Succeeding? An Empirical Assessment of Judicial Performance, 152 U. PA. L. REV. 1105, 1180 (2004) (explaining that Federal Circuit judges employ two methodological approaches to claim construction, which leads to distinct results); see also Peter Lee, Patent Law and the Two Cultures, 120 YALE L.J. 2, 25-60 (2010) (describing the gulf between the "formalist" approach and the "holistic" approach in patent law jurisprudence).

161. See Wagner \& Petherbridge, supra note 160, at 1163 (finding "ample evidence of panel dependency in claim construction at the Federal Circuit").

162. For a discussion of this split, see Jason Rantanen, Arlington Industries v. Bridgeport Fittings: "The Specification is the Heart of the Patent", PATENTLY-O (Jan. 25, 2011), http://patentlyo.com/patent/2011/01/arlington-industries-vbridgeport-fittings-the-specification-is-the-heart-of-the-patent.html?utm_target/ $=$ feedburner\&utm_medium $=$ feed\&utm_campaign=Feed $\% 3 \mathrm{~A}+$ typepad $\% 2 \mathrm{FANIN}+$ $\% 28$ Dennis + Crouch $\% 27 \mathrm{~s}+$ Patently-O $\% 29$.

163. Brad Lyeria, Understand the Two Approaches to Claim Construction, Managing Intell. Prop., Nov. 2011, at 47, 49, http://jenner.com/system/ assets/publications/7425/original/47-49 Claim construction.pdf?1321996721 (describing two approaches as "the invention method" and "the words method").

164. With the exception of an experiment in which panel composition was announced one week prior to oral arguments that ran in 2005. See Kristen Osenga, Linguistics and Patent Claim Construction, 38 RUTGERs L.J. 61, 72 n.50 (2006) (describing the experiment and the ways in which litigants may have altered their behavior in response).

165. I use Judge Bryson here by way of example; as Petherbridge and Wagner demonstrated, he is not the only judge to exhibit preferences along the holistic-proceduralist spectrum. See Wagner \& Petherbridge, supra note 160, at 1155 . 
Put more broadly, there is a strong perception among practicing attorneys that attorneys matter; that the choices and arguments they make, and the preparation that they put in, make a difference when it comes to claim construction. ${ }^{166}$ As one attorney observes, claim construction "is where skilled appellate advocates can most frequently turn defeat into victory at the Federal Circuit."167

Here are a few of tips for winning claim construction offered by one litigation consultant: "[k]now your judge," "[u]nderstand your tech tutorial procedure," "[w]ork with your expert," and "practice." 168 One can find numerous variations on this theme. ${ }^{169}$ The idea here is that a well-prepared attorney, who has done her research, will be more successful at having a judge adopt her client's claim constructions than one who is less prepared. Not unlike how an elite

166. This is true not only for claim construction, but also for arguments before the Federal Circuit more generally and probably for nearly all legal arguments, as I discuss below. As another example, consider Rachel Clark Hughey, Effective Appellate Advocacy Before the Federal Circuit: A Former Law Clerk's Perspective, 11 J. APP. PRAC. \& PROCESS 401 (2010) (offering guidelines and tips on being an effective advocate before the Federal Circuit). As a few examples, Hughey notes that while clerking on the court "I came to realize that the ineffective attorneys often made the same mistakes, and that their mistakes would have been easy to remedy had the lawyers only realized they were making them," and "[w]ithout a strong appellate brief, it is going to be hard to win your case." Id. at 401, 404 (footnote omitted); see also Meredith Addy, Appellate Strategy Before the U.S. Court of Appeals for the Federal Circuit, in PAtent Litigation, Negotiation, AND Settlement, Leading Lawyers on Strategies for EfFectively Resolving PAtent Disputes (2006) ("Experienced Federal Circuit practitioners know how to prepare an appeal tailored to the unique experience Federal Circuit judges have.").

167. Roy Wepner, Overview of Practice Before the United States Court of Appeals for the Federal Circuit, in BUILDING \& ENFORCING INTELLECTUAL Property VAlue: An InTERnational Guide For the BoARdroom 2003 100, 103 (2002), http://ldlkm.com/pdfs/wepner.pdf ("Simply stated, a case can be salvaged at the Federal Circuit on the issue of claim construction simply through better advocacy.").

168. Ryan H. Flax, The Litigation Consulting Report: 11 Tips for Winning at Your Markman Hearing, A2L Consulting (Oct. 10, 2013, 2:25 PM) (emphasis added), http://www.a2lc.com/blog/bid/67898/11-Tips-for-Winning-at-YourMarkman-Hearings.

169. See, e.g., Ed Mannino, Five Ways Trial Lawyers Can Defeat Patent Trolls in Litigation (Updated), ED MANNINO (Jan. 21, 2013), http://edmannino.com/blog/five-ways-trial-lawyers-can-defeat-patent-trolls-inlitigation/; Andrew Y. Piatnicia, The Road to a Successful Markman Hearing, LAw360 (May 22, 2008, 12:00 AM), http://www.law360.com/articles/57110/theroad-to-a-successful-markman-hearing; Robert T. Haslam \& Thomas B. Walsh IV, Tips for Constructing Your Markman Hearing (July 27-28, 2006), http://www.texasbarcle.com/Materials/Events/5964/2158.htm. 
athlete prepares and trains in order to be in the best possible position to win.

Consider a parallel line of thought: It is well established that the availability of resources gives parties an advantage in patent litigation. ${ }^{170} \mathrm{In}$ other words, litigation outcomes tend to favor the party who spends more money on the litigation. This makes sense from a market-driven perspective: Parties with more resources are able to hire more effective counsel; are able to invest more resources in finding prior art (if they are the accused infringer); can allow their counsel to spend more time thinking about case strategies; can hire more prestigious experts; can develop more challenging and complex doctrines, such as the doctrine of equivalents; and can argue more creative strategies (such as subject matter eligibility, which prior to 2010 was widely regarded as a fairly minor doctrine) ${ }^{171}$ and other cost-driven components of patent litigation. ${ }^{172}$

170. See John W. Schlicher, Settlement of Patent Litigation and DisPUTES 33 (2011) (noting that a party with more resources has an edge in litigation because "[f]or many, if not most, patent issues, there is likely to be a positive relationship between litigation costs and both the owner's probability of winning and the infringer's probability of avoiding losing"); Rebecca Love Kourlis, Jordan M. Singer \& Natalie Knowlton, Reinvigorating Pleadings, 87 DENV. U. L. REV. 245, 282 (2010) ("[T]he ultimate success or failure of a claim for patent infringement must turn on specific facts - facts that require time, energy, and money to uncover during the discovery phase."); Kimberly A. Moore, Forum Shopping in Patent Cases: Does Geographic Choice Affect Innovation?, 83 J. PAT. \& Trademark OfF. Soc'y 558, 590, 591 \& n.125 (2001) (reporting that financial resources correlate with patent litigation success due to litigation costs of forum shopping).

171. See Craig Allen Nard \& R. Polk Wagner, Patent Law 122 (2008) ("Although defining the scope of patentable inventions - and requiring them to be 'useful' - are perhaps the most basic requirements of any patent system, the actual application of $\S 101$ in the modern patent law is rather rare.").

172. Of course, I'm not making the claim that litigation outcomes are dictated solely by who spends the most money; that obviously would be absurd and lacks any empirical support. See, e.g., Kimberly A. Moore, Populism and Patents, 82 N.Y.U. L. REV. 69, 91 (2007) (noting advantages in patent litigation, including having more money and the ability to hire better lawyers but finding other factors that dictated outcomes, particularly the idealized nature of the individual inventor). The point is merely that money spent in patent litigation can affect outcomes, from the construction of claim terms to issues of validity and infringement. This is because there is substantial flexibility in the scope of the rights that a patent gives; those probabilities are not random, but rather are affected by the actions of the parties themselves, and even who the parties to the litigation are. See id. 
Patent law is not, of course, the only area where the lawyer's skills can alter the outcome. ${ }^{173}$ As Judge Frankel observed about our litigation system, "[i]n principle, the paramount objective is the truth." 174 But the adversarial process lets the truth get lost: "The business of the advocate, simply stated, is to win if possible without violating the law. (The phrase 'if possible' is meant to modify what precedes it, but the danger of slippage is well known.) His is not the search for truth as such." ${ }^{\prime 15}$ And consider Judge Frankel's description of the zealous advocate:

Unfettered by the clear prohibitions actual "knowledge" of the truth might impose, lawyers may be effective and exuberant in employing the familiar skills: techniques that make a witness look unreliable although the look stems only from counsel's artifice, cunning questions that stop short of discomfiting revelations, complaisant experts for whom some shopping may have been necessary. The credo that frees counsel for such arts is not a doctrine of truth-seeking.

The litigator's devices, let us be clear, have utility in testing dishonest witnesses, ferreting out falsehoods, and thus exposing the truth. But to a considerable degree these devices are like other potent weapons, equally lethal for heroes and villains. It is worth stressing, therefore, that the gladiator using the weapons in the courtroom is not primarily crusading after truth, but seeking to win. If this is banal, it is also overlooked too much and, in any event, basic to my thesis. ${ }^{176}$

Indeed, it would not be much of a stretch to say that all litigation outcomes are affected, to some extent, by the respective skill, investment, experience, and knowledge of the parties, and the strategic and tactical decisions they make along the way. Wouldn't

173. See, e.g., Frank B. Cross, The Error of Positive Rights, 48 UCLA L. REV. 857, 881-82 (2001) ("Because of the resources required by litigation, the 'basic architecture' of the litigation process means that wealthier, repeat participants [will succeed more often in litigation.] Repeat players can structure the process in ways that disadvantage those with fewer legal experiences. This is especially true for broad 'cause-oriented' litigation. Richer interest groups achieve greater success in court. Successful litigation, especially in complex matters, requires top quality lawyers who might be especially costly to retain. Those unable to retain the best counsel are more likely to lose in court and consequently set adverse precedents for similarly situated parties." (footnotes omitted)); see also Marc Galanter, Why the "Haves" Come Out Ahead: Speculations on the Limits of Legal Change, 9 LAw \& SoC'Y REV. 95, 114-19, 135-51 (1974) (explaining how parties' typology can affect litigation outcomes and outlining strategies for reform).

174. Marvin E. Frankel, The Search for Truth: An Umpireal View, 123 U. PA. L. REV. 1031, 1033 (1975) (emphasis added).

175. Id. at 1037 .

176. Id. at 1039 . 
this suggest that everything is malleable, thus rendering the concept meaningless?

No. If all legal determinations are malleable, then malleability is far more of an important concept than the literature has yet recognized. But I am not making such a broad claim. First, as I indicated at the outset, malleability exists along a spectrum; some legal rights can be more malleable than others. Malleability does not imply complete malleability. Many legal rights are less malleable than, say, the patent right. Consider, for example, the boundaries set out in a deed. Sometimes they can be subject to dispute, but boundary disputes tend not to dominate the litigations where rights in real property are being contested. ${ }^{177}$ Certainly not in a way that boundary disputes dominate patent litigation. ${ }^{178}$

Second, there is a difference between the effect a skillful lawyer or other party resources can have on the outcome of a dispute and their impact on the scope of the (patent) right itself. Unlike a case like, say Palsgraf v. Long Island Railroad Co., where the

177. One property hornbook, for example, devotes nine pages to boundary issues in real property descriptions. See William B. Stoebuck \& Dale A. WhitMan, The LAW OF Property 819-27 (3d ed. 2000). Many property casebooks barely touch on the issue.

178. See, e.g., BESSEN \& MEURER, supra note 131, at 235-53; Mossoff, supra note 12, at 1696-1704; Mark A. Lemley \& A. Douglas Melamed, Missing the Forest for the Trolls, 113 CoLuM. L. REv. 2117, 2170-74 (2013). It is not uncontested, however: in challenging what he refers to as the "trespass fallacy" Adam Mossoff argues that there is a lack of empirical evidence that real property boundaries are as stable and determinate as patent law commentators envision. See Mossoff, supra note 12 , at 1704-08. But care must be taken in overreading claims of indeterminacy in real property law, at least with respect to claim scope. Central to Mossoff's argument is that boundary issues in real property must be considered in terms of the estate boundaries, not just the physical description of the land. See id. at 1704 ("If the boundaries of patents are to be compared to the boundaries of real estate, then commentators and judges must include the doctrines that secure the temporal, geographic, and functional dimensions and which together define the scope of a property right secured in an estate."). To be sure, this is an important focus, but the appropriate comparison to patent law, then, is to consider the entire bundle of rights granted by statute (i.e., the right to make, use, offer to sell, sell, and several additional rights as spelled out in 35 U.S.C. $\S 271$ (2012)), along with questions of assignment and ownership, which implicate additional issues and levels of complexity beyond just the question of the boundaries of the invention itself. In other words, if the discussion is about claim scope, then analogies to disputes over deed descriptions can be appropriate; if the discussion is about the scope of the patent right along all dimensions, then analogies should be drawn to the full scope of the estate. Cf. Saurabh Vishnubhakat, Cognitive Economy and the Trespass Fallacy: A Response to Professor Mossoff, 65 FlA. L. REV. ForUM 38, 40 (2014) (suggesting a scaling down of the trespass analogy in patent law). 
question was whether causation was present in the series of events, and thus whether the railroad was liable, ${ }^{179}$ patent litigation almost always involves disputes over the scope and strength of the right itself. Using an analogy to real property, the primary issues in patent infringement suits that parties typically fight over are the metes and bounds of the parcel itself and whether the premises encompassed by those boundaries are legitimately capturable. In patent law those boundaries are nearly always in play. ${ }^{180}$

The consequences of a particular claim construction add an additional layer because a claim construction outcome can alter the rights with respect to others. When a patent holder wins or loses on claim construction, that claim construction can bind the patent holder with respect to not only its immediate opponent, but also everyone else the patent holder seeks to assert the patent against. ${ }^{181}$ Worse, when a patent holder loses on validity, the subject claims become invalid against the world. ${ }^{182}$ And while a claim construction decided

179. 162 N.E. 99, 101 (N.Y. 1928).

180. The distinction between rights and outcomes may be too formalistic for some. One might characterize the issue in Palsgraf as the extent of tort duties and thus, the parties' corresponding rights. Viewed in that light, Palsgraf arguably embodies malleability since a more skilled advocate could conceivably have persuaded one more judge, such that the way those duties were defined could have been different. But I do think there's enough of a difference between the defined property-like rights of a patent and the scope of duties under tort law such that we can describe the former as pretty clearly involving the malleability of a right and the latter as merely conceivably involving the malleability of a right.

181. See, e.g., E.Digital Corp. v. Futurewei Techs. Inc., 772 F.3d 723, 72627 (Fed. Cir. 2014) (holding the district court correctly applied collateral estoppel by using an earlier claim construction of an identical limitation). E.Digital reiterates, however, that collateral estoppel does not apply to unrelated patents, see id. at 727 ("These distinctions reinforce the well-understood notion that claims of unrelated patents must be construed separately."), and there must be a final judgment on the merits. $I d$.

182. See Blonder-Tongue Labs., Inc., v. Univ. of Ill. Found., 402 U.S. 313, 324-26 (1971). Gideon Parchomovsky and Alex Stein refer to the different categories of defenses as "individualized" and "general" defenses with noninfringement being a paradigmatic individualized defense, as it "does little to shield third parties from future infringement suits." See Gideon Parchomovsky \& Alex Stein, Intellectual Property Defenses, 113 Colum. L. REv. 1483, 1499 (2013). In my view, Parchomovsky and Stein overstate to some extent the potential effect of a noninfringement finding that flows from a narrow claim construction, $c f$. Roger Allan Ford, Patent Invalidity Versus Noninfringement, 99 CORNELL L. REV. 71, 110 (2013) ("[A noninfringement] judgment can benefit others if it results in claim interpretations that make the patent less likely to be infringed."), although I acknowledge that there is an asymmetry. See Jason Rantanen, Slaying the Troll: Litigation as an Effective Strategy Against Patent Threats, 23 SANTA Clara 
in one case may not similarly be used against third-party, potential infringers, there can be some persuasive effect. ${ }^{183}$

Malleability, then, is not just about one side winning due to its greater litigation assets or more skillful arguments. Rather, it is about the potential for parties to alter the scope and strength of rights that are good as against the world. That potential is very real in patent law, particularly because the very scope of the patent right is in dispute, ${ }^{184}$ and it is only natural that the skills, experience, knowledge, and preparation of each party's attorneys are brought to bear on precisely that point.

Related to this point is the very nature of the claim construction process, which enhances patent malleability well beyond other legal rights where the scope of rights may be relatively fixed. Claim construction is fraught with competing doctrines and principles with complex precedents stirred together with an array of canons of greater or lesser strength. ${ }^{185}$ One of the most useful articles on claim construction, ${ }^{186}$ Patent Claim Construction: A Modern Synthesis and Structure Framework, represents the efforts of three leading voices in patent law to bring some coherence and organization to the process. ${ }^{187}$ It is a mere 120 pages long. ${ }^{188}$ There are entire treatises

Computer \& High Tech. L.J. 159, 179-80 (2006). The more important point, however, is that while there may be an asymmetry, both noninfringement outcomes and invalidity outcomes can negatively affect the patent right.

183. See CHISUM, supra note 124, § 19.02(e)(iii) (describing examples of cases in which prior construction is given persuasive effect); Larry Akers et al., The Interpretation of Patent Claims, 32 Am. InTELL. Prop. L. AsS'N Q.J. 1, 71-72 (2004) (articulating an/the argument that if claim construction is a matter of law, then prior constructions should be entitled to stare decisis, but observing that it is "[a]n open issue [] whether the determination of claim construction from a prior litigation is entitled to stare decisis"); David Krinsky, The Supreme Court, Stare Decisis, and the Role of Appellate Deference in Patent Claim Construction Appeals, 66 MD. L. REV. 194, 198-99 (2006) (concluding that under Markman, claim construction is entitled to stare decisis effect but arguing that this holding should be jettisoned).

184. Cf. Dan L. Burk, Dynamic Claim Interpretation, in InTELlectuAL Property AND THE COMMON LAW 107, 113 (Shyamkrishna Balganesh ed., 2013) ("The language of patent claims, defining a property right, is not simply efficacious as between the parties: it is intended to be efficacious against the world.").

185. Immunocept, LLC v. Fulbright \& Jaworski, LLP, 504 F.3d 1281, 1285 (Fed. Cir. 2007) ("Claim scope determination is a question of law that can be complex in that it may involve many claim construction doctrines.").

186. Indeed, I recommend it to my patent law students.

187. Peter S. Menell, Matthew D. Powers \& Steven C. Carlson, Patent Claim Construction: A Modern Synthesis and Structured Framework, 25 BERKELEY TECH. L.J. 711 (2010).

188. Id. 
devoted to just the subject of claim construction. ${ }^{189}$ Layered on top are theories of claim construction, such as the holistic-procedural divide discussed above. Of course, just knowing the principles and precedents isn't enough: Being able to effectively apply them is yet more challenging. As one treatise on claim construction observes, "[a]nnouncing the substantive precepts of patent claim interpretation is one thing, but applying them to the facts of a case can be much more perplexing, particularly where precepts can be in opposition to one another, and district judges cannot always tell which one(s) apply in a particular case." ${ }^{190}$ Here, then, the skill and knowledge of the litigator can potentially matter a great deal. ${ }^{191}$

As a final point, it is also important to recognize that even claim ambiguity itself can be a deliberate strategic choice. Patent drafters may choose, for example, claim terms and phrases that maximize future malleability so that they can later argue for either expanding or narrowing depending on the circumstances. "Sometimes [claim] ambiguity is the result of sloppy drafting, and sometimes it appears that claims are drafted with a degree of indefiniteness so as to leave room to later argue for a broad interpretation designed to capture later-developed competition." ${ }^{192}$

189. See, e.g., Thomas L. Creel, Practicing Law Inst., Patent Claim Construction and Markman Hearings (2013); Robert C. Kahrl, Patent Claim CONSTRUCTION (2001).

190. Edward Manzo, Claim Construction in the Federal Circuit $§ 1: 2$ (2015).

191. See Intellectual Property Litigation, V\&E LAW, http://www.velaw.com/practices/IntellectualPropertyLitigation.aspx [https://web. archive.org/web/*/http://www.velaw.com/practices/IntellectualPropertyLitigation.as px] ("Since 1995, our lawyers have conducted over 50 Markman hearings achieving a successful and decisive claim construction from the courts in the vast majority of these cases. Our success before the Federal Circuit is no different we have obtained favorable decisions for our clients in nearly every appeal we have handled."); Patent Litigation and Trial, WiLliams MORGAN P.C., http:/www.wmalaw.com/patentlitigation (last visited Sept. 18, 2015) (listing successful Markman hearing outcomes and hyperlinking to court documents).

192. 3M Innovative Props. v. Tredegar Corp., 725 F.3d 1315, 1334 (Fed. Cir. 2013) (Plager, J., concurring) (emphasis added); see also Brad Lyeria, Words Method vs. Invention Method of Claim Construction, AM. BAR Ass'N (Feb. 20, 2012), http://apps.americanbar.org/litigation/committees/intellectual/articles/winter 2012-words-invention-claim-construction.html ("It is no secret that claims are sometimes deliberately drafted to include some uncertainty as to their scope for the precise reason that it may give the patentee an advantage if the patent is litigated."); cf. Robert C. Faber, FAber on Mechanics of PAtent Claim Drafting $\S 10: 1.1[\mathrm{~B}]$ (6th ed. 2008) ("The claim drafter should preferably have a claim 
Such intentional ambiguity can grant maneuverability to lawyers arguing over claim construction in the future.

\section{E. Patents as Multiple, Semi-Independent Bundles of Rights}

Patent law also contains a profoundly structural aspect whose defining characteristic adds to the malleability of the patent right.

Here, I refer to the composition of the "patent right" as actually consisting of semi-independent bundles of rights that the patent holder can selectively assert. While patents are often spoken of in terms of a bundle of rights, those rights are generally conceived of as being merely different in type, i.e., the exclusive right to make, the exclusive right to sell, the right to alienate, etc. ${ }^{193}$ In other words, the rights to a particular "invention." But this is not the way that patents are actually structured. Rather than being a single bundle of rights, they are instead composed of multiple sets of bundles of overlapping rights. What do I mean by this?

As discussed above, patent rights are based on claims. But patents rarely contain only a single claim. Instead, they typically involve multiple claims that are structured in a particular way: from broad to narrow. ${ }^{194}$ Patent-claim sets start with an "independent" claim that defines the invention in relatively broad terms. For example, consider the following independent claim from a recently litigated patent:

1. A method of enhancing the chemical stability of an aqueous composition comprising a therapeutically-effective amount of a prostaglandin, wherein the method comprises adding a chemically-

generic to all alternatives and to all embodiments, in addition to other claims specific to particular ones of the alternatives or embodiments.").

193. See, e.g., Daniel H. Cole, The Law and Economics Approach to Property 2 n.16 (Ind. Univ. Maurer Sch. of Law, Working Paper No. 277, 2014), http://ssrn.com/abstract=2375933 ("[V]irtually all economists, as well as most legal scholars, treat property as a 'bundle' of discrete rights and obligations."); see also Coll. Sav. Bank v. Fla. Prepaid Postsecondary Educ. Expense Bd., 527 U.S. 666, 673 (1999) (noting that exclusionary rights, the "hallmark of a protected property interest," are "one of the most essential sticks in the bundle of rights that are commonly characterized as property" (citation omitted)). It's important to keep in mind that the bundle analogy refers to each stick as a discrete type of right such as the right to possess or the right to alienate. See Vaupel Textilmaschinen KG v. Meccanica Euro Italia S.P.A., 944 F.2d 870, 875 (Fed. Cir. 1991).

194. In some instances, the examiner may require this. See MANual of Patent Examining Procedure $\S$ 608.01(m) (9th ed. 2014) ("Claims should preferably be arranged in order of scope so that the first claim presented is the least restrictive."). 
stabilizing amount of a polyethoxylated castor oil $[(\mathrm{PECO})]$ to the composition. ${ }^{195}$

This claim sets out the boundaries of the invention at a particular level of abstraction. Next, consider claims 2 through 4, which "depend" from claim 1:

2. The method of claim 1 wherein the polyethoxylated castor oil is present at a concentration between about $0.02 \mathrm{wt} \%$ and about $20.0 \mathrm{wt} \%$.

3. The method of claim 2 wherein the polyethoxylated castor oil is present at a concentration between about $0.1 \mathrm{wt} \%$ and about $5.0 \mathrm{wt} \%$.

4. The method of claim 3 wherein the polyethoxylated castor oil is present at a concentration between about $0.5 \mathrm{wt} \%$ and about $2.0 \mathrm{wt} \% .{ }^{196}$

Claim 2 refers back to claim 1, adding a limitation about the concentration of the PECO. Claim 3 refers back to claim 2, further narrowing the concentration. And claim 4 narrows the concentration even more. The result is a funneling down of the invention from the broadest claim of rights to the narrowest. Note that the narrowing need not be with respect to a specific limitation, as it is here. It could be along other axes, such as claim 12, which reads "[t]he method of claim 1 wherein the composition is a topically administrable ophthalmic composition."'197

This formal structure produces significant consequences. There is an old saying in patent law that " $[t]$ he stronger a patent the weaker it is and the weaker a patent the stronger it is." 198 This saying captures a key tension in patent law: A broad claim can encompass a greater scope, but it is more susceptible to invalidity because it covers more categories of prior art; may be more likely to fail written description or enablement; or may not comply with the other patentability requirements. ${ }^{199}$ In contrast, a narrow claim is more likely valid, but weak in the sense that it likely encompasses fewer

195. U.S. Patent No. 5,631,287 col. 8 11. 57-61 (filed Dec. 22, 1994).

196. Id. at col. 8 1. 62-col. 91.3.

197. Id. at col. 10 11. 52-53.

198. Giles S. Rich, The Proposed Patent Legislation: Some Comments, 35 Geo. Wash. L. ReV. 641, 644 (1967) (emphasis omitted) ("To explain, a patent that is strong in that it contains broad claims which adequately protect the invention so they are hard to design around is weak in that it may be easier to invalidate and is therefore less likely to stand up in court because the claims are more likely to read on prior art or be broader than the disclosed invention, and for other reasons defense lawyers can devise. On the other hand, the patent with narrow claims of the kind the Patent Office readily allows quickly without a contest is weak as protection and as incentive to invest but strong in that a court will not likely invalidate it.").

199. See id. 
infringers or users and is also easier to design around. ${ }^{200}$ Patent drafters write patents to take advantage of both possibilities: that ideally a narrow claim will be used in the future, but perhaps it will be necessary to deploy a broad claim. Patents rarely contain just a single broad or narrow claim, but rather consist of a series of broad and narrow claims that funnel down from the broad and more likely invalid, to the narrow (and easier to design around) but more likely valid.

Furthermore, the sets of rights granted by a patent-the claims - are independent in the sense that the validity of one is not necessarily dependent on the validity of another. ${ }^{201}$ This independence is not complete (hence why I refer to them as semiindependent sets of rights); rather, they are still linked to some extent. But the important point is that determinations as to the validity of multiple patents claims are, to some degree, independent of one another.

The result of this structure is that rather than consisting of a tidy bundle of rights, patents end up being comprised of multiple sets of semi-independent bundles of rights that overlap with one another and that include both bundles of strong-but-narrow rights and weakbut-broad rights. Unsurprisingly, many of the paradigmatic validity disputes in patent law turn out to be over this latter set of claims: the weak-but-broad rights. ${ }^{202}$ The narrow-but-strong claims were likely still around, in the background, and typically protected the core embodiment of the patent holder's technology; of course, they may also not be infringed. ${ }^{203}$

200. Id.

201. 35 U.S.C. § 282(a) (2012) ("Each claim of a patent (whether in independent, dependent, or multiple dependent form) shall be presumed valid independently of the validity of other claims ....").

202. See, e.g., Graham v. John Deere Co. of Kan. City, 383 U.S. 1, 4, 37 (1966) (invalidating a patent that sought to cover the field of "Clamp[s] for vibrating Shank Plows" because the patent was considered obvious in light of prior art); Consol. Elec. Light Co. v. McKeesport Light Co., 159 U.S. 465, 468, 475-77 (1895) (invalidating a claim that sought to cover the field of incandescent lamp conductors consisting of "carbonized fibrous or textile material" because the patentee only enabled a species of the genus claim); O'Reilly v. Morse, 56 U.S. 62, 62 (1853) (invalidating a claim that sought to cover "electro-magnetism, however developed, for making or printing intelligible characters, signs or letters at any distance" because, in part, the patentee did not enable the full scope of the claim).

203. Cf. Allison, Lemley \& Schwartz, supra note 65 , at 1788-89, 1784-85 (finding that accused infringers tend to win on noninfringement more than invalidity); Michael Risch, A Generation of Patent Litigation, 52 SAN DIEGO L. REV. 67, 125 (forthcoming 2015) (finding the same). 
This multi-claim structure also allows patent drafters to include both highly ambiguous (and vague) claims and those that are much more specific to the embodiments of the patent. It represents a critical difference between patent rights and any form of traditional property regime. Imagine if someone could draft deeds this way. The deed might start with,

The boundaries of my land extend as far as one can see from the big oak tree, but if a court finds that's unclear, then they extend as far as $I$ can see from the big oak tree. But if a court holds that that's not clear enough, then they extend 100 paces outward from the big oak tree. ${ }^{204}$

And on and on. Patent claims basically work like that, by forming a structure that gives a great deal of choice and flexibility to the patent holder.

\section{F. Post-Issuance Revision at the Patent Office}

A patent holder can also alter the formal scope of the patent right after the patent is issued. ${ }^{205}$ Two primary mechanisms are particularly relevant: reissue proceedings ${ }^{206}$ through which patent holders can seek modification of patent claims with certain restrictions, and ex parte reexamination, ${ }^{207}$ which can also result in post-grant modification of claims. ${ }^{208}$ While these mechanisms do have limitations, ${ }^{209}$ they allow for some adjustment of the claims in a patent.

This form of claim malleability is described extensively by Tun-Jen Chiang. Chiang offers a land-based analogy:

204. See Rantanen, supra note 74, at 53.

205. For an extensive discussion of this ability, and why it is costly, see Chiang, supra note 15.

206. See CHISUM, supra note $124, \S 15.01$.

207. Id. § 11.07. Claim scope can also be changed during other post-issuance proceedings such as inter partes review, although in practice thus far that mechanism has been highly limited. See Rantanen, supra note 95. And although technically, continuations do not alter the scope of an issue patent, one can certainly take the position, as Chiang does, that continuations are a way to effectively alter the formal scope of the patent right after a patent has issued. I discuss this below in the context of patent families and portfolios. See infra Section III.G.

208. See CHISUM, supra note 124, § 11.07[4] (stating that if a reexamination is initiated, "[t]he patent owner may file a statement on the new question and add new or amended claims").

209. Reissuance, for example, does not allow the patentee to "recapture subject matter intentionally surrendered to obtain the original patent" or, after two years, to "enlarge[] the scope of the original patent." See id. § 15.01. 
Imagine a real property system where your neighbor is permitted to move his fence to encompass your new house. Moreover, he then sues you for trespassing and evicts you from the house. A real property system with such constantly moving fences would quickly break down, as people move fences in self-serving ways, litigate evictions, and stop building houses.

In comparison, a patentee is permitted to change his claims throughout the life of the patent, generally at-will with few substantive limits. ${ }^{210}$

As Chiang observes, these mechanisms do not allow unfettered modification of the patent right: It is still subject to the same constraints as the original patent claims. ${ }^{211}$ And there are important limitations on this form of formal claim malleability: Broadening claim scope is generally not allowed, and "intervening rights" mean that the patent holder cannot obtain a monetary or injunctive remedy against products "made or sold prior to the completion of a reissuance or reexamination proceeding." $" 212$ But that post-issuance claim amendment exists at all does, in Chiang's words, "turn[] an important patent-law principle - that claim language defines the patentee's right to exclude — on its head." 213

\section{G. Malleability and Patent Portfolios}

Although to this point I have spoken of patent rights as subsisting in the individual patent document, another view of patents is to look at them as a portfolio or a family. The basic idea behind the portfolio approach to patents is that owning a group of related patents is more valuable to the patent owner than the individual patents would be; in other words, "the whole is greater than the sum of its parts." 214 This is because, as Gideon Parchomovsky and Polk Wagner explain, the holder of a patent portfolio benefits from several offensive and defensive strategic advantages that holders of individual patents do not. ${ }^{215}$ In essence, they argue, the portfolio of related patents works like a "super-patent" that can grant tremendous market power to the portfolio owner. ${ }^{216}$

210. Chiang, supra note 15 , at 525.

211. See id. at 534 ("This does not mean, of course, that patentees may amend to claim anything under the sun.").

212. Id. at 532-33.

213. Id. at 535 .

214. Gideon Parchomovsky \& R. Polk Wagner, Patent Portfolios, 154 U. PA. L. REV. 1, 5 (2005).

215. Id. at 7 .

216. Id. 
If patent portfolios are like "super-patents," then they are also "super-malleable." The scope of a patent is limited by its claims, which, as discussed above, are limited to some extent by the original filing. Collections of multiple, sometimes not even procedurally related, patents are not so limited. True, patent law doctrines still limit them, particularly those involving prior art. But within the portfolio context, scope can be added or subtracted by obtaining new patents and acquiring others from third parties. And because the whole is greater than the sum of the parts, strategically acquiring additional patents can alter the scope of the portfolio's rights of exclusion by more than that of the individual patent. In other words, it is not the acquisition of the new patent per se that is the malleable aspect of portfolios; rather, it is the effect that the acquisition has on the exclusionary scope of the portfolio above and beyond the scope of the individual patent that is malleable in nature. ${ }^{217}$

Nor does a patent owner need to assemble a complex portfolio to take advantage of the malleable nature of patents. Today, patents are often thought of not as individual documents but as part of a family of patents that is related by their connection to a common written description. ${ }^{218}$ Patent families are different from portfolios in that families are necessarily procedurally related. For example, a patent family might include an original patent application that ultimately issued as a patent (the "parent"); a continuation filed off that original patent that, also, issued as a patent at a later date (the "child"); and a continuation-in-part that issued off the second patent in the family that, too, issued as a patent at a later date (the "grandchild"). ${ }^{219}$ All three patents share some portion of (or all of, in

217. Cf. Michael Risch, Patent Portfolios as Securities, 63 Duke L.J. 89, 116 (observing that in a portfolio sale, the value of the portfolio "depends on the buyer's enforcement efforts[, while i]n a portfolio license, the success depends on the seller's (licensor's) efforts to maintain validity and license to other entities" (second emphasis added)).

218. See John R. Allison et al., Valuable Patents, 92 Geo. L.J. 435, 460 (2004) (defining "patent families" as "related patents issuing from the same original application").

219. See CHISUM, supra note 124, § 13.03[1]. In Chiang's discussion of postissuance modification of the formal scope of the patent claim, he groups continuations together with procedural mechanisms that allow for modification of words of the patent claim in the original patent. See Chiang, supra note 15, at 53334. Technically, as Chiang recognized, they are not. But given the concept of malleability articulated in this Article, I tend to agree with Chiang on a practical level. Patent rights are malleable, and both continuations and post-issuance proceedings are forms of malleability. Nevertheless, the distinction highlights an important limitation on these various mechanisms for altering the formal scope of 
the case of the first two) the original written description; as a result, they all have some ability to claim the benefit of the original filing date. ${ }^{220}$

This leads to the primary benefit of patent families: They permit the owner of the family to write and file new claims that get to rely on an earlier filing date. ${ }^{221}$ Thus when a patent challenger asserts invalidity based on a lack of "newness" (anticipation and obviousness), she must rely on prior art from before the filing date of the first patent in the family. ${ }^{222}$ This significantly complicates the task of invalidating those later added claims. The result is a very malleable set of rights that sophisticated patent holders can shift and alter to their advantage. ${ }^{223}$

\section{IS THERE A THEORETICAL JUSTIFICATION FOR THE MALLEABILITY OF PATENT RIGHTS?}

Understanding that patent rights are malleable requires a rethinking of how patent law theory operates. It seems fairly unquestionable that malleability comes with substantial costs. Less clear is whether there is a meaningful justification. One place to begin is with the legal mechanisms that allow for the malleability of patent rights. In that space, the doctrine of equivalents, which I have not discussed in depth yet, helps shed some light on this question.

The doctrine of equivalents is a mechanism that allows a patent holder to claim that a product or process infringes a patent even if it

the patent claim: Generally speaking, rights don't begin until a particular version of a claim actually issues or is at a minimum published (in the case of published applications containing claims). Thus, exclusive rights in a continuation patent won't actually begin until that patent issues (or, for purposes of 35 U.S.C. § 154(d) (2012), when claims are published), which can substantially impact damages-based remedies.

220. CHISUM, supra note 124, § 13.03[1].

221. See id. § 13.03[2]. The analysis becomes more complex when it involves continuations-in-part, which may or may not be able to claim priority back to the original filing date, an issue that depends on whether they are supported by the original disclosure. Id. $\S 13.03[3]$ ("Claims that are dependent upon new matter added by a continuation-in-part ('CIP') application are entitled to the filing date of the CIP, not that of the parent application.").

222. See id. § 13.01.

223. Cf. Kingsdown Med. Consultants, Ltd. v. Hollister Inc., 863 F.2d 867, 874 (Fed. Cir. 1988) ("[It is] improper to amend or insert claims intended to cover a competitor's product the applicant's attorney has learned about during the prosecution of a patent application."). 
is not within the literal scope of the claim. ${ }^{224}$ It works by treating an element of the product or process as an equivalent of a particular claim limitation. ${ }^{225}$ For example, a patent claim covering a coneshaped rail car might not literally encompass an octagonal-shaped railcar. ${ }^{226}$ But under the doctrine of equivalents, that octagonal shape could be treated as an equivalent, and the accused rail car be ruled infringing. ${ }^{227}$ In effect, the scope of the claim extends beyond its literal scope.

The doctrine of equivalents thus might be considered part of the malleability of patent rights, particularly under one normative justification for the doctrine of equivalents: that it "is to protect the patentee against later-developed technology." 228 For example, "transistors in relation to vacuum tubes, or Velcro ${ }^{\circledR}$ in relation to fasteners." ${ }^{229}$ And as with claim construction, the additional scope provided by the doctrine is subject to alteration by the parties after the patent issues, as arguments about equivalency are made and developed, and are formalized into legal decisions. ${ }^{230}$

But the after-arising technology rationale for the doctrine of equivalents is of limited use in considering malleability more broadly. The doctrine of equivalents is one-sided: It allows only for expansion of claim scope, not contraction. ${ }^{231}$ But many forms of malleability discussed in this Article are two-sided. The patent right may be expanded or reduced by parties after the patent issues.

224. See Warner-Jenkinson Co. v. Hilton Davis Chem. Co., 520 U.S. 17, 23 28 (1997).

225. Id. at 24-28.

226. A classic example of the doctrine of equivalents from Winans $v$. Denmead, 56 U.S. 330, 340-44 (1853).

227. Id. at 346-48 (Campbell, J., dissenting).

228. Timothy R. Holbrook, Equivalency and Patent Law's Possession Paradox, 23 HARV. J.L. \& TECH. 1, 17 (2009).

229. Festo Corp. v. Shoketsu Kinzoku Kogyo Kabushiki Co., 344 F.3d 1359, 1369 (Fed. Cir. 2003).

230. Consider, for example, the expansion and contraction of the doctrine of equivalents through the late 1990 s and early 2000 s, which manifested in a series of opinions. See, e.g., id.; Warner-Jenkinson, 520 U.S. 17. The judges and Justices who wrote those opinions were not writing on a blank slate with a fresh pencil; they were responding to the arguments and positioning that the parties themselves presented, and as each opinion issued, the parties came up with creative new ways to respond to the new development.

231. To be sure, there is much lawyering that is done over whether the doctrine can apply and, if so, the extent to which it expands the literal claim scope, with parties arguing on each side. But the essence of the doctrine of equivalents involves an expansion of literal claim scope to encompass something beyond what the applicant actually stated in its claims. 
Malleability in general, then, carries the potential for as much lost as gained. It is not simply a way of encompassing after-arising technology. ${ }^{232}$

The unidirectional malleability of the doctrine of equivalents does offer an insight into the broader concept, however. In particular, while the doctrine of equivalents can only expand the scope of the claims, it is subject to many limitations. ${ }^{233}$ Thus, the doctrine of equivalents does not offer an unfettered ability to push out the boundaries of claim scope. To the contrary, this form of malleability is tightly constrained. Why is this? A possible explanation is that when a right exhibits unidirectional malleability in a particular dimension, strong restrictions on that malleability are particularly necessary in order to counterbalance that malleability.

A second justification for the doctrine of equivalents is that it is intended to compensate for the limitations of human beings and human language. ${ }^{234}$ Human beings are not omniscient; language is not a perfect medium of communication. The doctrine of equivalents allows a patent holder to expand beyond the literal language because our system recognizes the impossibility of perfectly claiming a technological advance. ${ }^{235}$

Perhaps, then, malleability is unavoidable. Because language is imperfect, and because legal rules are to some degree indeterminate, the result is necessarily going to be that parties are going to argue

232. If there were a meaningful reverse doctrine of equivalents, under which "a device is so far changed in principle from a patented article that it performs the same or a similar function in a substantially different way, but nevertheless falls within the literal words of the claim" would not infringe, Graver Tank \& Mfg. Co. v. Linde Air Prods. Co., 339 U.S. 605, 608-09 (1950), then perhaps the malleability here would be bidirectional, and this bidirectional form of malleability would be a sophisticated way of dealing with the problem of after-arising technology. But the doctrine is, as Peter Lee observes, "moribund." See Peter Lee, The Accession Insight and Patent Infringement Remedies, 110 Mich. L. REV. 175, 189 (2011); see also Tate Access Floors, Inc. v. Interface Architectural Res., Inc., 279 F.3d 1357, 1368 (Fed. Cir. 2002) ("Not once has this court affirmed a decision finding noninfringement based on the reverse doctrine of equivalents.").

233. For examples of the limitations on the doctrine of equivalents, see NARD, supra note 28, at 547-87.

234. See Festo Corp., 535 U.S. at 731 ("The language in the patent claims may not capture every nuance of the invention or describe with complete precision the range of its novelty. If patents were always interpreted by their literal terms, their value would be greatly diminished.").

235. Cf. Nautilus, Inc. v. Biosig Instruments, Inc., 134 S. Ct. 2120, 2129 (2014) ("The definiteness requirement, so understood, mandates clarity, while recognizing that absolute precision is unattainable."). 
about the result, and the party with the better arguments - not necessarily perfect arguments, just better arguments - is going to win. Along a similar vein, perhaps malleability is simply the inevitable result of the difficulty of dealing with after-arising technology; that is, technological developments that do not occur until after the patent issues. ${ }^{236}$

But this is less a justification and more a mere consequence. It does not tell us that malleability is good; it simply tells us that malleability is unavoidable and perhaps too costly to eliminate in its entirety. Malleability, then, becomes like the problem of ambiguous claims: We might like to get rid of it, but we can't, so it is simply tolerated.

Then there is the view that malleability is bad: that there is no viable theoretical justification for malleability and substantial theoretical justification for patent rights being fixed. Tun-Jen Chiang expresses this view in the context of formal modification of patent claims:

The fact that claims can be so easily changed, and with retroactive effect, calls into question their function as property boundaries. Property rights generally have a degree of stability to facilitate investment by their owners and others. A property whose boundaries are constantly shifting is a bad vehicle for investment - both for the property owner and any potential trespassers. Imagine, for example, that the fence on your land was constantly moving in random directions. This would make it very risky for you to improve your land, such as by building a house on it, because tomorrow the fence might move inwards and take away your ownership. On the other hand, your neighbors cannot improve their land either, because your fence might move outwards and strip them of their rights. To top it off, nobody would want to buy your land precisely because its future value is so hard to determine. Because patent claims are easily changed, they serve as poor boundaries, undermining the patent system for everyone. ${ }^{237}$

Chiang's point sounds loudly for the broader concept of malleability advanced in this Article. If what really matters are the actions and arguments of the parties after the patent issues, then it becomes particularly difficult to rely on a reading of the patent document itself. Patent rights, then, look a lot less like what we consider to be quality rights to land and a lot more like what we might consider to be poor rights to land: land in which the boundary is not merely shifting randomly, but shifting in response to the

236. For a discussion of the problems of after-arising technology, see Kevin Emerson Collins, Enabling After-Arising Technology, 34 J. CORP. L. 1083 (2009).

237. Chiang, supra note 15 , at 530 (citations and emphasis omitted). 
actions of others. Under this view, we should be particularly cautious when we observe malleability in the patent right, particularly areas where there is substantial room for the actions of the parties to affect the scope and strength of the right.

In addition, if patent rights are truly malleable and are subject to expansion and contraction by entities who can pull the right levers, then past cost-benefit assessments of the patent system may no longer be valid - particularly if patent rights are becoming more malleable. In this scenario, the scope of the rights relative to what was originally granted has changed. In other words, if a patent was granted with scope $X$ now has scope $X+Y$, we might be concerned that the public has not actually received anything in return for this expanded grant.

Of equal importance is the effect of malleable patent rights on the patent incentive. The incentive is effectively minimized if patent scope is due more to the types of arguments that litigators make in enforcement, or on other things that the inventor has little or no control over at the time of filing. The inventor's contribution is of relatively less value, and the skilled patent asserter's contribution is of greater value.

Similarly, any expansion of the malleability of patent rights might call into question some of the doctrinal choices that were made in a past era. If the balances of the patent system were struck when patents had scope $X$, but now have scope $X+Y$ or $X-Y$ due to their malleable nature, it might be that competing weights of incentive versus competition may no longer be rightly balanced. ${ }^{238}$

In addition, like uncertainty, malleability distorts the abilities of parties to know, ex ante, the boundaries of the exclusive rights that patents grant. ${ }^{239}$ This inability makes it more difficult for parties to transact. It may raise the costs of transactions because parties aren't quite sure what they're transacting about and must spend additional resources defining that substance. It may discourage capital investment because the investor is unwilling to invest in an activity where the potential return is both uncertain and can be diminished by the legal arguments of competitors. It can diminish incentives to commercialize, both in terms of new technologies (because the exclusive rights offered by the patent may be shrunk by competitors)

238. Assuming, of course, that they ever were rightly balanced.

239. For a discussion of how uncertainty can impose costs on economic activity in the innovation context, see Peter S. Menell \& Michael J. Meurer, Notice Failure and Notice Externalities, 5 J. Legal ANALYsis 1, 8-9 (2013). 
and by competitors (because the exclusive rights obtained by an innovator may be expanded to encompass the competitor's different product).

Finally, while malleability may well come with substantial costs, those costs need to be weighed against the doctrinal cures. Malleability is both a general aspect of patent rights and comprised of multiple separate doctrines and issues. Viewed as a general matter, malleability may be undesirable. But when specific doctrines-doctrines such as the doctrine of equivalents or claim construct - are examined separately, it may be that the policy choices that underlie those malleability-creating doctrines outweigh the consequences of that malleability. Similarly, while issues such as lawyerly influence may not be expressed through doctrine, legal rules can, to some extent, cabin that influence. But even as they do, the costs of such rules may be too great to justify the benefits of reduced malleability.

\section{CONCLUSION}

This Article argues that patent rights should be conceptualized not as rights frozen at the time of issuance, but as malleable rights that can be altered by various actors after the patents have issued.

What, then, are the consequences of recognizing that patent rights are malleable? It turns out that they can be quite significant. ${ }^{240}$ Consider, for example, the primary narrative articulated by supporters of emerging patent monetization strategies: that such strategies are economically efficient because they ensure that inventors receive their just rewards for the teachings of the patent and because they reduce transaction costs.

But the persuasive ability of this narrative falters when viewed through the lens of malleable rights. Because patent rights are malleable, patent owners can actively expand the scope and strength of those rights independent of the patent's technological teachings. In other words, patent owners can extract revenue not only by simply reducing transaction costs or adding to the value of the underlying technology, or (in the conventional challenge to the narrative) by reaping nuisance costs, ${ }^{241}$ but also by expanding the patent right itself

240. I explore these consequences in greater detail in a separate essay, How Malleability Matters. Rantanen, supra note 95.

241. See, e.g., Colleen V. Chien, Reforming Software Patents, 50 Hous. L. REV. 325, 342 (2012) (discussing "the incentive that exists to assert patents because defending against patent demands is expensive, and, therefore, induces settlement"); 
after it has issued. This insight leads to an alternative narrative, one that does not revolve around efficiency gains.

But malleability can work the other way, too: It can be used to push back against the scope and strength of a patent, even if the teachings of the patent reflect an important advancement in the art. Accused infringers may well be able to push back on patent scope and strength during litigation. Furthermore, challengers have the benefit of administrative mechanisms that expressly allow challengers to push back on scope or even terminate the patent right after it has issued. In particular, the recently implemented mechanisms of inter partes review and Covered Business Method Review affect the malleability of the patent right in a remarkably one-sided way. ${ }^{242}$ Furthermore, the consequences of these new mechanisms are not limited to just so-called "low quality" patents, but can affect a much broader range of patents.

Conceiving of patent rights as malleable changes the ways in which contemporary issues in patent law are understood: The effect of nonpracticing entities may be to expand the scope and strength of patent rights rather than to merely solve transaction failures, and expanded administrative post-issuance review of patents at the patent office has the effect of increasing patent malleability in a one-sided way. Given the prevalence and potential expansion of patent malleability, the lack of a clear theoretical justification for malleability of patent rights raises serious questions about continued movement in this direction.

Jonathan S. Masur, Costly Screens and Patent Examination, 2 J. Legal ANALYSIS 687, 707-11 (2010) (discussing the problems of nuisance patents); Ted Sichelman, Commercializing Patents, 62 STAN. L. REV. 341, 368 (2010) (stating that nonpracticing entities "are often termed 'patent trolls,' because they tend to exploit litigation and licensing market defects to extract unwarranted rents from commercializers, usually on patents that the commercializer was completely unaware of before the NPE's demand for payment"); Ranganath Sudarshan, Nuisance-Value Patent Suits: An Economic Model and Proposal, 25 SANTA ClarA COMPUTER \& High TECH. L.J. 159, 160-62 (2008).

242. Rantanen, supra note 95. 